\title{
LABOR RELATIONS IN THE BROADCASTING INDUSTRY*
}

\author{
Charles H. Towert
}

I

INTRODUCTION

The term "labor relations" is generally applied to the relationship existing between management and organized labor in a particular company or industry. This is a narrow, though perhaps useful, definition. In the larger sense, labor relations covers the full range of human problems in a business situation. Even where an industry is highly organized, many of the important human relations problems fall outside the union-management relationship. Where an industry is only partially organized, such as broadcasting, the significance of policies and practices not shaped by collective bargaining becomes even greater.

An evaluation of union-management relations in an industry may be difficult, but it is much easier to handle than an evaluation of the entire human relations climate of that industry. Perhaps this is a very practical reason why the first subject gets more attention than the second. This article, too, will take the more limited approach. The union-management relationship in broadcasting will be the central theme.

Using the narrower frame of reference, what are the factors which have shaped union-management relations in broadcasting? Why, for example, is union organization in broadcasting relatively limited? What factors have molded the bargaining units that do exist? What have been the forces establishing the contract patterns that are found? In short, if as to labor relations, broadcasting has an individual stamp, how did it get that way?

A thoroughgoing analysis of this problem is outside the scope of this article. It would constitute an article-almost a book - by itself, one in which the legal or quasilegal manifestations of labor relations would be significant not in themselves, but as symptoms of more fundamental causal relationships. Here we shall suggest some of the more basic factors which seem to explain certain facets of broadcasting labor relations.

It might be generalized that the labor relations of any industry is shaped by three related factors: the nature of the product or service; the structure of the industry producing the product or service; and, finally, the characteristics of the jobs falling

* Collaborating in the preparation of this article were two colleagues of the author at the NAB, James $H$. Hulbert and Harold G. Ross.

† A.B. I942, Williams College; I.A. 1943, Harvard Business School; LL.B. 1949, Boston University. Member of the Massachusetts bar. Manager, National Association of Broadcasters' Employer-Employce Relations Department. 
within that structure. We shall look briefly at each of these in terms of the broadcast environment.

\section{A. The Nature of the Product}

Broadcasting is a service industry providing entertainment and information to the public and time plus an audience to the advertiser. As such, the product is timeoriented, semi-continuous, and community-centered. All three factors have their effect on broadcasting labor relations. A time-oriented product or service is one that is related to a particular point in time, which broadcasting is by definition. It means that the product cannot be stored like shoes or steel rails in anticipation of a production stoppage. Once passed, it is gone forever. The semi-continuous nature of the service (for most stations, fourteen to eighteen hours a day, seven days a week) has made many broadcasters reluctant to risk the interruption of an important community service and also reluctant to risk breaking, even temporarily, an audience listening or viewing habit. Contract clauses also reflect some of the problems of almost round-the-clock operation. Finally, the community-centered nature of station operations undoubtedly has made management and, perhaps to some extent, the unions sensitive to public reaction when contemplating some of the more drastic moves on the chessboard of bargaining.

From a production point of view, broadcasting consists of an electronic impulse and program content. In radio today, with the increasing use of automatic and semi-automatic equipment and with the increasing reliance on recorded music, the production process is being progressively simplified. It is much simpler than the production process in many businesses. One technician and one announcer can keep a station on the air at any one time. More can be usefully used and are used in certain situations. Fewer are needed if voices are recorded and automatic transmitter equipment has been installed. The trend toward simplification of operation in radio has had an important effect on the balance of power between broadcasting unions and management.

A TV station's production process is much more complicated than that of radioa difference which is partially offset by a heavier reliance on network programming. Where one technician may be used in radio, five may be needed in TV. Only one announcer at a time is usually on the air, but a production team, other than technicians, to provide him with materials is necessary. Of course, even in television, if local live programming is reduced both in quantity and complexity (perhaps replaced by film and network), as it can be for at least limited periods of time, the crew necessary to keep a station on the air is small-an important factor at the bargaining table.

Network broadcasting is concerned with program production and sales. As a production operation, network broadcasting is complicated, volatile, expensive, and nerve-wracking-just about the other end of the spectrum from station production. Network radio is complicated enough; network television much more so. The more 
elaborate efforts require a precise coordination of artistic, craft, and electronic skills on a grand scale. The objective is the creation of a custom-made product at a cost of fifty to one hundred thousand dollars or more, which will normally be used only once at a specific point in time. This is a production environment-to borrow a famous industry phrase-well-calculated to keep you in suspense-and in ulcers. It is also a production environment which gives substantial advantage to organized groups that are a part of it.

\section{B. The Structure of the Industry}

The structure of an industry substantially affects its labor relations in both character and extent. Structure is a function of the nature of the product or service, the technology utilized to produce it, the economic environment, and government regulations affecting the industry. The interplay of these molding forces is a story in itself-a story beyond the scope of this article.

In considering the structure of broadcasting and its effect on labor relations, the following observations come most readily to mind. First, the producing units at the station level are small and geographically dispersed; secondly, they are competitive only within a restricted local market, with a relatively few units serving each market; and, finally, for important segments of the industry, profits over a period of years have been substantial.

Because of its tremendous daily impact on millions of Americans, many people have an erroneous impression of the over-all size of the broadcasting industry and an equally erroneous impression of the size of the producing units. In terms of employment and dollar volume of business, the industry as a whole is small ${ }^{1}$ and so are the producing units. ${ }^{2}$ Only the networks in broadcasting get out of the small-business category. ${ }^{3}$ Technology and the availability of low-cost (for example, records in radio) or "no-cost" (network service) program material have made low-budget producing and distributing units an economic possibility. FCC emphasis on local and competitive service in as many communities as possible has made small-

\footnotetext{
${ }^{1}$ Radio and television broadcasting, stations, and networks, employed 85,000 full- and part-time people in 1956. Survey of Current Business, July 1957, p. 19. Gross sales amounted to roughly \$1.38 billion. Final TV Broadcast Financial Data-1956, FCC Press Release, Aug. 22, 1957, and NARTB estimate for 1956 based on Final AM-FM Broadcast Financial Data-1955, FCC Press Release, Dec. 27, 1956.

${ }^{2}$ The average (mean) radio station has a staff of about 20 employees- 17 full-time and 3 part-time. This average ranges from ro employees in markets of less than ro,000 population to $40-45$ cmployecs in markets of over I million population. NARTB, 1955 RAdio-WAGEs, Hours, EMpLoymENT pt. 3, at 44 . Total station employment in TV, is on the average (median), 63-with 50 full-time and 13 part-timc. In markets of less than 25,000 population the median drops to 32, while in markets of over 1 million, the typical station employs $x 28$ people. NARTB, I957 Televiston-WaGEs, Houns, EMrployment 5, $35,48^{\circ}$. The typical (median) radio station grossed approximately $\$ 100,000$ in 1956 , while its TV counterpart took in slightly over $\$ 900,000$. Radio operations in markets of less than ro,000 had a typical revenue of $\$ 64,000$, while in markets of over I million, revenue was $\$ 300,000-\$ 400,000$. In TV, the median ranges from $\$ 330,000$ to slightly over $\$ 3$ million in markets of less than 25,000 and ovcr I million, respectively. NARTB, I957 Radio Financist SuRvey 4, 10, 12, 26; NARTB, 957 Television Financial SURVEX 4, IO, 20.

${ }^{3}$ The four national networks, excluding their owned-and-operated stations, employ about 9,500 people, and, with the three regional networks, they gross slightly over $\$ 500$ million. Final TV Broadcast Financial Data-1956, FCC, Press Release, Aug. 22, 1957.
} 
unit operation a reality. Geographical dispersion is part of the same development. ${ }^{4}$ Taken together, small size and geographical dispersion have made unionization difficult because of cost and communications problems. Furthermore, the closer management-employee relationship often found in the small company and the traditional small-town hostility towards unionization have been added obstacles.

The second generalization on structure-the lack of competition between stations in different markets and the limited number of broadcasters in each market-has allowed unionization to proceed on a market-by-market basis, without placing the unionized stations at a serious competitive disadvantage. ${ }^{5}$ Market insulation has also permitted a wider diversity in contract terms among the various markets than might otherwise have existed.

The profitability of the broadcasting industry in recent years-a condition directly related to the structure of the industry-has had a profound impact on labor relations. Radio, as a commercial business, got off the ground in the early thirties. It grew steadily and prospered substantially in the late thirties and through the I940's. By any standards of comparison, profits and profit margins for most of the companies were large. ${ }^{6}$ But competition from within, caused by a trebling in the number of stations in the last twelve years, and competition from without, caused by the growth of television, have significantly reduced the profitability of the radio industry. ${ }^{7}$ During the same period, television has grown from nothing to a billiondollar industry, with unusually high profits for the well-established segments of the industry. ${ }^{8}$ This situation has resulted from a variety of factors, chief among them being a temporary limitation on competition imposed in part by FCC indecision on allocations and in part by the growth cycle of the business. The resulting profitability has undoubtedly reduced management's willingness to resist substantial union demands.

\section{The Jobs}

Flowing from the nature of the product and the structure of the industry are the jobs themselves-the jobs needed to produce the product or service. The characteristics of these jobs-for example, the degree and type of skill-obviously have an impact on an industry's labor relations. Of the four basic nonsupervisory jobs in station broadcasting-announcer, technician, clerical, and sales-only the first two have

- Radio stations are now operating in roughly 1500 different communities, while there are 302 cities in which video facilities are located. (NARTB estimate for radio and FCC information for TV, as of October I, 1957.)

${ }^{\circ}$ Of the 302 cities with commercial TV stations, 18I are one-station communities, 76 have 2 stations, 33 have 3 stations and 12 have 4 or more stations. In radio, there are 1227 local areas with only 1 station, 236 with 2 stations, 90 with 3 stations, 52 with 4 or 5 stations, and 84 with 6 or more AM facilities.

'Ross, The Economics of Broadcasting in the United States, in Sertous Broadcasting Today 39 (1957).

${ }^{7}$ Ibid. See also, NARTB, 1957 Radio Financias SURvey, op. cit. supra note 2.

${ }^{9}$ NAR'TB, 1957 Telentston Financial SuRvey, op. cit. supta note 2. 
received any significant attention from the unions. ${ }^{9}$ While most jobs have many characteristics, relevant here are only those characteristics which have an effect on the industry's labor relations. They are: number of jobs by bargaining unit, skill level, skill relationship to other jobs in the organization and in other industries, and job stability.

The job of broadcast technician is, for those who are fully qualified, a highly skilled, although nonprofessional, occupation involving the operation and maintenance of complicated electronic equipment. Not every broadcast technician is fully qualified. In fact, at the typical station, there will normally be substantial differences in ability among staff technicians, and a certain amount of job specialization will naturally develop, with the best technicians, for example, regularly handling the most difficult work, such as maintenance and the building of new equipment. This specialization, which can result in substantial differences in job content from a skill point of view, is normally not reflected in job title, nor is it usually reflected in wage scales. In the early days of radio, the job involved a new and thus a unique skill. Today, the basic elements of the jobs, or at least the skills needed to perform it, are found in many segments of American industry which use electronic technicians.

There probably are about 14,000 nonsupervisory technicians working in the broadcasting industry today. In many small radio stations-and these stations constitute the great bulk of stations-only one technician is employed. A medium-size station may have three or four, with the largest stations normally employing not more than fifteen or twenty. In television, the number will vary from a minimum of five or six to a maximum of fifty or sixty. The three national networks together employ about three thousand broadcast technicians.

The implications for collective bargaining of the distribution of technicians are twofold. First, it is obvious that where there is only one technician, as there is in many small-market stations, and he is thus the chief engineer, there is little likelihood of organization, no matter what other factors may be involved. To some degree, the same is true where only two or three nonsupervisory technicians are employed. A second implication relates to the matter of bargaining strength. As will be noted in a subsequent section, where bargaining units are small and the facility can be operated, at least temporarily, by supervisory technicians with perhaps temporary part-time assistance from the outside, a union's bargaining strength is substantially affected.

The job of announcing is a talent, not a craft, occupation. Almost anybody with a couple of days of training can handle the mechanics of the job. Only a very few have that intangible combination of voice, personality, and, in television, looks to win the widespread public acceptance necessary to get to the top of the ladder. The replaceability of the skill, at least on a "get by" basis, has diminished union bargaining power at medium-size and smaller stations. On the other hand, the com-

\footnotetext{
${ }^{\circ}$ In small business, it is rare to find union organization among clerical and sales personnel. Salesmen
} are included in only one or two broadcasting industry agreements, and clerical employees in only a few more. 
petitive demand for top personalities who have a direct impact on audience and revenue has enhanced bargaining power at the large stations. A related fact, significant to the unions from an organizational point of view, is the individualistic and competitive nature of the performer's job and thus, to some extent, the type of person who is attracted to it.

Turnover among announcers tends to be high. For the most part, performing life is short-probably not more than ten or fifteen years at best-hence, the desire to move as fast and as far as individual ability permits. An additional factor contributing to turnover is the need for new voices and faces as audience tastes change and program formats are modified. High turnover plus the lack of any real professional identification, until a performer has climbed a substantial way up the ladder, have been limiting factors in the unionization of announcers.

Announcers and other performers at the network level are, in almost all cases, fully-qualified professionals, many of whom work on an occasional or per-program basis. Often they combine their work in broadcasting with activities in other sections of the entertainment business. The early and strong organization of this group is directly attributable to these facts.

With the foregoing analysis as a background, we shall look at the following manifestations of collective bargaining in labor relations: the bargaining units in broadcasting, the climate of bargaining, the contracts, and labor legislation affecting broadcasting.

\section{II}

\section{The Collective Bargaining Units}

There are several ways to measure the extent of bargaining in an industry. Two common methods are the number of employees organized and the number of contract units. The following figures on the extent of organization in broadcasting represent estimates based on information compiled from a variety of sources.

Of the approximately 85,000 people employed by radio and television stations and networks, about 16,000 , or nineteen per cent, are unionized. It should be noted that a substantial number of the 85,000 are, of course, executive and administrative personnel. Looking at the two basic job categories, estimates show that 8,500 , or sixtyone per cent, of the 14,000 nonsupervisory technicians in the industry are represented by unions, and 3,000 , or fourteen per cent, of the 21,500 staff and special program announcers are organized. ${ }^{10}$

The second method of measuring extent of organization shows that of the 493 television stations on the air, approximately I90, or thirty-nine per cent, have contracts covering technicians. ${ }^{11}$ The comparable figures in radio are 365 stations with

\footnotetext{
${ }^{10}$ Three thousand of the 8,500 are employed by the three national networks which program in both radio and television. Free lance performers employed on a casual or per-job basis, who make up the bulk of AFTRA membership, are not included in these figures.

${ }^{12}$ Where an AM and a TV station are commonly owned and located in the same market, a single contract normally covers the comparable skill group in both stations. However, for counting purposes here, they are treated as two separate contracts.
} 
technicians organized out of a total station population of 3,157 , thus giving a percentage organized of twelve per cent. Most of these contracts are found at stations in the first fifty markets in the United States.

Organization of announcers is more limited than among technicians. The number of announcer contracts with TV stations is approximately roo out of 493 stations, or twenty per cent. In radio, the figures are 200 out of 3,157 , or six per cent. Most of the unionized announcers are found in the first twenty markets.

At the larger stations, various other groups of employees may be represented. Performing musicians are generally represented by the AFM. Separate units of stagehands are found at a few of the larger television stations. There are a few units of film department employees, and even a few of office clerical employees.

The three national television networks and the four national radio networks are highly organized. A substantial percentage of their nonsupervisory employees are represented by various unions.

The figures showing percentage of contract units at the station level do not adequately reveal the full impact of collective bargaining in broadcasting. The key stations in the large markets are, for the most part, unionized. Contract settlements involving these stations have a direct impact on comparable stations in the same market and have a lesser, but still significant, effect on employment conditions in smaller unorganized markets.

Before examining in detail the structure of bargaining units in broadcasting, it may be helpful briefly to identify the unions which are active in the broadcasting field.

I. International Brotherhood of Electrical Workers (IBEW) -a large, old-line craft union, most of whose members are found in the electrical construction field. Other large segments are found in utilities and in manufacturing. Although probably less than one per cent of the union's more than 600,000 members are working in broadcasting, the IBEW represents more full-time broadcasting employees than any other union.

2. National Association of Broadcast Employees and Technicians (NABET) -a union formed in the middle ' 30 's to represent broadcasting technicians. NABET was a member of the old CIO and a number of years ago embarked on a deliberate policy of industrial unionism for broadcasting. The great bulk of its membership, which in 1955 was reported as 4,I00, is made up of technicians, not quite half of whom work for two of the national networks. 3. American Communications Association (ACA) - a union which several years ago was among a group of unions expelled from the CIO for alleged Communist domination. Its chief strength is among shipboard radio-telephone operators and in other areas of nonbroadcast communications. ACA units in broadcasting have over the past ten years been reduced to a handful in Philadelphia and New York. 
4. International Alliance of Theatrical Stage Employees and Moving Picture: Machine Operators of the United States and Canada (IATSE)-another old-line AFL union with primary bargaining interest in motion picture production, motion picture exhibition (projectionists), and the legitimate theatrein New York. Its strength in broadcasting consists of stagehands and related classifications at the network production centers in New York,. Chicago, and Los Angeles, and in a handful of station agreements. A number of these station contracts cover technicians as well as production employees. 5. American Federation of Television and Radio Artists (AFTRA)-a union organized under a different name in the middle ' 30 's to represent performers. and directors in network radio. It is now primarily a union of performers, claiming a membership of about 13,000, most of whom are free-lance artistsworking in the so-called talent pools in New York and Los Angeles.

6. American Federation of Musicians (AFM) -a well-known union representing professional musicians who perform in many segments of the entertainment industry. The union represents staff musicians employed by the networks and by some of the larger stations. Although the employment of staff musicians at the station level has declined in the past few years, according to official reports of the union, its members get more money from broadcasting than from any other single industry. ${ }^{12}$

There are other unions representing employees in broadcasting, but the number of people so represented is small. In this category are such unions as the Radio and Television Directors Guild, Television Writers of America, Screen Actors Guild (which does represent a substantial number of performers on film television shows), and a scattering of independent unions.

The term "bargaining unit" has two distinct but related frames of reference. One is the contract unit-that is, the identification of employees covered by the contract. The other is the appropriate unit-that is, the identification of those who may vote as a group in an NLRB election proceeding. ${ }^{13}$ Where a union wins an NLRB election, the subsequent contract unit usually coincides with the election unit. The election unit is based either on an agreement of the parties in a consent-election proceeding, or on a Board determination of the appropriate unit in a Board-ordered election following a hearing. Case material on appropriate units in broadcasting-or in any other industry for that matter-comes from those cases in which the Board has * ordered an election.

In determining what unit is appropriate the Board, over a twenty-year period, has built up a series of principles which are used as guides in the determination of each. particular case as it is presented. Technical jargon aside, what the Board tries to

12 ggth Annual Convention of the American Federation of Musicians of the United Statesand Canada, Proceedings I24-31 (I956).

${ }^{18}$ Section 9 (c) of the National Labor Relations Act, 61 STAT. I43 (r947), 29 U.S.C. $\$ 159$ (1952), gives the NLRB authority to determine appropriate bargaining units, but with relatively little congressional ${ }^{\pi}$ guidance as to the criteria to be used in making the determination. 
do is to put together a voting group of those employees who seem to have interests in common. Taken into consideration are such factors as the relationship of skills, homogeneity of wages, hours, working conditions and supervision, bargaining history, industry practice, company organizational structure, and union membership patterns. Literally thousands of cases in hundreds of industries have defined, elaborated, restricted, qualified, and, occasionally, confused these factors in their application to specific factual situations. The thread of consistency is occasionally hard to find-particularly where the specialized problems of a specialized industry are involved.

Board unit decisions in broadcasting did not emerge from a vacuum. ${ }^{14}$ They were formed, as in most industries, in the light of patterns of bargaining that had already existed. A few bargaining units were established in broadcasting in the late 1920's, but the real beginnings of collective bargaining in radio both at the network and station level took place in the I930's. The IBEW was active in organizing broadcast technicians during the early 1930's, before the Wagner Act was passed in I935. In that year, CBS signed an agreement with AFTRA's predecessor, an organization known as AGRAP (The American Guild of Radio Announcers and Producers). But it was not until about 1938 that there was any real expansion of unionism in broadcasting. The period of biggest union growth in broadcasting was the decade r940 to $\mathrm{x} 95^{\circ}$.

In these early beginnings were found the basic patterns of collective bargaining which have persisted down to the present time. The Musicians' Union was obviously interested in musicians; the Announcers' Union primarily in performers; and the International Brotherhood of Electrical Workers in technicians. Their expansion during the ' 30 's was gradual, involving principally the larger stations in the larger

16 The NLRB has always assumed-and most broadcasters have accepted the assumption-that the National Labor Relations Act (both the original Wagner Act of 1935 and the Taft-Hartley Act of x947) is sufficiently broad in terms of coverage to include all commercial broadcasting stations. Generally speaking, the law includes all businesses engaged directly in interstate commerce, engaged in the production of goods or services for interstate commerce, or engaged in activities affecting interstate commerce. National Labor Relations Board v. Jones \& Laughlin Steel Corp., 301 U.S. I (1937). The last reference obviously covers a lot of ground-just how much ground nobody is quite sure. NLRB jurisdiction was unsuccessfully contested by small stations in a number of cases. Mike Benton, $d / b / a$ General Broadcasting Co., 8I N.L.R.B. 422 (1949); Nebraska Broadcasting Company, Inc., 85 N.L.R.B. 694 (x949); Joe V. Williams, Jr., d/b/a WDXB Broadcasting Station, 85 N.L.R.B. 752 (I949); Vetcran's Broadcasting Company, 87 N.L.R.B. 199 (1949). Even without an audible signal going outside the state of origination, the Board has based jurisdiction on in-flow, referencing such items as network affiliation, wire service connection, use of out-of-state transcriptions, etc. The affecting-commerce concept has not been used, but undoubtedly could be as a last resort.

In I95I, as part of its program of limiting its activities to the more important aspects of interstate commerce, the Board announced that it would no longer take jurisdiction over radio and TV stations doing a gross volume of business of less than $\$ 200,000$ a year. Hanford Broadcasting Company, xio N.L.R.B. 1257 (1954). In construing this rule, the Board has combined AM and TV station revenues where operated by the same ownership in the same market. South Bend Broadcasting Corp., 116 N.L.R.B. 1166 (1956). Also combined were radio revenue and newspaper revenue where the radio station was operated as a department of the newspaper in the same market. Elizabeth $R$. Lynett and Edward J. Lynett $\mathrm{d} / \mathrm{b} / \mathrm{a}$ The Scranton Times, III N.L.R.B. 780 (1955). Whether group-owned stations will be counted scparatelye or jointly has not been decided by the Board. 
markets and the networks. Board procedures were undoubtedly used in a substantial number of cases on a consent-election basis, but few formal decisions directing elections in broadcasting were handed down by the NLRB during the first five years of the Wagner Act. In the '40's, particularly after World War II, it became much more common in the broadcasting industry for bargaining units to be established only after elections conducted by the NLRB. Within the past five years this has been the almost uniform method of resolving a question of representation.

Bargaining in broadcasting has traditionally been on a single-employer and a single-plant basis. Multiple-employer bargaining is the rule in some network negotiations, for example, in the negotiations with AFTRA, RTDG, and the American Federation of Musicians. The NLRB has held appropriate a multiple-employer bargaining unit covering performing talent on live network television shows ${ }^{15}$ and of writers employed by the three TV networks to work on network TV shows. ${ }^{16}$

At various times in the past, in a handful of markets, some or all of the stations have bargained as a group, although the degree of commitment on the part of each employer has varied considerably from case to case. The Board has not certified multiple-employer units at the station level in broadcasting, and there probably is less multiple-employer bargaining today than there was five years ago. Group-owned stations are generally handled, in matters of collective bargaining, on a single-plant or single-station basis. The NLRB has rarely been asked to certify a unit including employees at more than one station where the stations are commonly owned. The cases suggest that the Board will normally not include employees of more than one station in a single bargaining unit, unless there is a significant degree of centralized control over the stations and unless there is a bargaining history of inclusion of employees from two or more stations in a single contract. ${ }^{17}$

An important exception to the single-plant tradition has been the network negotiations with the technicians' unions. CBS with the IBEW, and ABC and NBC with the NABET, each bargain on a system-wide basis with their technicians. The contracts cover technicians on network programs as well as technicians at the networkowned stations. ${ }^{18}$

Most bargaining units in broadcasting reflect a grouping of employees according

${ }^{16}$ American Broadcasting Co., Inc., 96 N.L.R.B. 8I5 (x95 $)$.

${ }^{10}$ National Broadcasting Co., Inc., ro4 N.L.R.B. 587 (I953).

${ }^{17}$ In Allen B. Dumont Laboratories, Inc., 80 N.L.R.B. I72 (1948), and Fetzer Broadcasting Co., Iro. N.L.R.B. 316 (1954), the Board determined as appropriate units of technicians involving employees at more than one station. There was in each case a bargaining history on a multiple-station basis as well as a substantial degree of integration between the stations involved. In the absence of such bargaining history, the Board rejected an employer argument for a unit of employees at its three stations in Inter-City Advertising Company of Greensboro, N. C., Inc., 89 N.L.R.B. xI03 (I950).

${ }^{18}$ Several exceptions to this general practice regarding technicians exist. They have normally arisen. from situations in which a different union from that representing the network technicians generally has bargaining rights at a station subsequently acquired by the network. The Board has recognized, aside from these exceptions, system-wide units of network technicians. See, for example, Columbia Broadcasting System, Inc., ro8 N.L.R.B. 1468 (1954), where the Board permitted technicians at a newly acquired station to indicate whether or not they wished to be merged into a nationwide unit covering: CBS technicians. 
to recognized skill such as announcing or technical work. Often this conforms to the employer's departmental structure. A few units have been set up on what in NLRB terminology is referred to as a plant-wide basis-that is, all or almost all nonsupervisory operating employees. ${ }^{19}$ The largest stations may have four or five contract units, the two most important of which will cover announcers and technicians. Most stations that have any collective bargaining will have either their announcers and technicians represented or only their technicians. Network labor relations are far more complicated. CBS and NBC, the two largest networks in terms of number of employees, each have over ioo separate contracts, although most of them -cover relatively small bargaining units.

Many of the specific bargaining unit problems in broadcasting are reflected in NLRB representation case decisions. A consideration of the more important decisions will give perspective on the scope and variety of these problems.

\section{A. Bargaining Unit Problems Involving Announcers}

The organization of performers in broadcasting started at the networks with a union organized to represent performers and directors. The first bargaining units were established without benefit of formal NLRB decisions. The Board, therefore, when finally confronted with the problem, took the view that performers-including -announcers, actors, and singers-formed a sufficiently homogeneous and identifiable skill group to constitute by themselves an appropriate unit. ${ }^{20}$ The unit description has normally been in terms of classification. ${ }^{21}$ Occasionally, AFTRA has asked for the inclusion of nonperforming program department employees in the same unit with announcers and other performers, and the Board normally has gone along with such requests. ${ }^{22}$ From the early decisions, it seems reasonably clear that the union has been basically interested in performers, but did not hesitate to take in nonperforming personnel when such inclusion fitted in with its organizational purposes.

In a I95I case involving a small station, the NLRB rejected AFTRA's request for a unit of announcers only and designated a unit of all nonsupervisory program department employees. ${ }^{23}$ A year later, the same basic problem was presented in several cases arising from AFTRA's attempt to organize announcers in the Norfolk-

${ }^{19}$ With company and union agreement, the Board found appropriate stationwide units of all nonsupervisory operating employees in Palm Beach Broadcasting Corp., 59 N.L.R.B. 640 (1944); Federated Publications, Inc., 74 N.L.R.B. 1054 (1947); and Carolina Broadcasting System, Inc., II-RC-872, October I, 1956. Company requests for such units in the face of a union request for a unit limited to particular skill or departmental grouping have been uniformly rejected. Louis G. Baltimore, 57 N.L.R.B. 16x I

(1944); Shamrock Broadcasting Co., KXYZ, 39-RC-549, February 5, 1953.

${ }^{20}$ KMOX Broadcasting Station, Io N.L.R.B. 479 (1938).

${ }^{21}$ Atlanta Journal Co., 59 N.L.R.B. 673 (1944) (a unit of staff announcers); Badger Broadcasting Co., 64 N.L.R.B. 1456 (1945) (a unit of "all full-time and part-time announcers and commentators"); 'Roderick Broadcasting Corp., 78 N.L.R.B. 406 (1948) (a unit of "all station announcers"); Delaware Broadcasting Co., 82 N.L.R.B. 727 (I949) (a unit of "all staff announcers").

${ }^{22}$ West Central Broadcasting Co., 77 N.L.R.B. 366 ( 1948 ) (a unit of "all announcers, singers and -continuity writers"). A request for the addition of nonperforming personnel was denied in Badger Broadcasting Co., supra note 21 .

${ }^{23}$ Westchester Broadcasting Corp., 93 N.L.R.B. 1346 (r951). 
Hampton Roads market. Over union objection, the Board, in its initial decisions, included performing as well as nonperforming program department personnel in the same units. ${ }^{24}$ On a motion to reconsider, the decisions were reversed, and a majority of the Board accepted AFTRA's request for a unit of all who "regularly or frequently" appeared before the microphone or camera. ${ }^{25}$

It appears that the Hampton Roads formula is the rule that would be used today in both radio and TV station cases. Consequently, if a petitioning union wants to limit its representation to performing talent who regularly or frequently appear before the microphone or camera, such a unit will be found appropriate. On the other hand, if the request is for a broader unit including closely associated nonperforming program department employees, it will also be accepted as appropriate.

Network broadcasting has created an unusual bargaining unit problem in regard to performers. Traditionally, the networks have negotiated with AFTRA (and its predecessors) so-called network codes covering performers on network shows originating in New York, Chicago, and Los Angeles-the primary network origination centers. Many of the performers on these shows are employed by agencies, advertisers, or package producers, all of whom have been happy to let the networks carry the negotiating ball. They sign letters of adherence agreeing to abide by the terms of the codes as negotiated, a practice which seems to maintain the fiction that, for this purpose at least, they are not the employers. ${ }^{26}$

The NLRB ran into the problem in a case involving performers on live network television shows. ${ }^{27} \mathrm{~A}$ unit of all performing talent, except musicians, on live network television originations in New York, Chicago, and Los Angeles was designated, despite Board Member Murdock's dissenting view that the Board had no statutory authority to find appropriate a unit largely made up of employees not employed by

14 Hampton Roads Broadcasting Corp., 98 N.L.R.B. I090 (1952); Norfolk Broadcasting Corp., 98 N.L.R.B. 1095 (1952).

${ }^{35}$ In the second decision in the Hampton Roads case, Hampton Roads Broadcasting Corp., I0o N.L.R.B. 238 (1952), a majority of the Board accepted AFTRA's contention that it was primarily a union of performers and that announcers, together with other performers, constituted an identifiable skill group with sufficient differentiation from other program department employees to constitute a separate bargaining unit. Board members Herzog and Murdock vigorously dissented, pointing to the integrated nature of small-station program departments, prior AFTRA petitions including nonperforming program department employees with performers, and the injunction contained in $\$ 9(c)(5)$ of the Taft-Hartley Act precluding the Board from using extent of organization as a controlling factor in determining an appropriate unit. See also Norfolk Broadcasting Corp., roo N.L.R.B. 244 (I952); WTAR Radio Corp., roo N.L.R.B. 250 (1952); and Pennsylvania Broadcasting Co., roo N.L.R.B. 254 (1952). In one early case, Miami Valley Broadcasting Corp., 70 N.L.R.B. ror5, ror6 (r946), the Board had described as appropriate a unit including "all employees of the Employer who appear before the microphone in a professional capacity."

An important, though perhaps somewhat theoretical, objection to the Hampton Roads formula is the fact that it defines the bargaining unit in terms of work instead of classification. Over a period of years, the NLRB has shown a sensible determination not to decide work jurisdiction problems in representation case proceedings-and, thus, has used classifications rather than work to define bargaining units. The Hampton Roads decision is not consistent with this traditional approach.

${ }^{26}$ In McCann Erickson Corp., I07 N.L.R.B. 1492 (I954), the Board found certain agencies to be the employers of performing talent used in the production of programs in Puerto Rico.

${ }^{27}$ Ämerican Broadcasting Co., Inc., 96 N.L.R.B. 815 (r951). 
the named employers, that is, the networks. The majority view represents a practical accommodation to a unique unit problem.

Beyond the question of basic unit definition, where announcers are concerned, there have been the usual fringe classification problems-some of them unique to broadcasting, others comparable to those found in most industries. The more important of these fringe classification problems are discussed briefly below:

\section{Announcer-Control Operators}

The announcer who handles the control board, along with his regular announcing duties, has been consistently held by the Board to be primarily an announcer, with his control-board work merely incidental to the basic announcing job. ${ }^{28}$ In contract units, the same principle has been recognized, although in a handful of contracts, particularly on the West Coast, the transfer of control-board operation from technicians to announcers has resulted in the insistence by the technicians' unions that the announcer-control operators carry membership cards in both AFTRA and the technician union.

\section{Special Program Announcers}

Most, but not all, announcer contracts cover specialists such as farm directors, sportscasters, and home economists, along with regular staff announcers. When presented with the issue in a representation case, the Board has almost invariably included both groups in a single election unit. ${ }^{29}$

\section{Part-time and Free-Lance Performers}

The term "free-lance performer" is widely used in broadcasting. Unfortunately, it has no precise meaning. This fact has caused a certain amount of confusion in Board decisions as well as created some problems at the bargaining table. Essentially a free-lance performer is a part-time employee who performs on a single program or series of programs. In some of the larger markets, there are so-called free-lance codes covering free-lance performers, most of whom are professional announcers who work on a nonexclusive basis for various stations or for agencies or sponsors. Where there is no free-lance code, the staff contract may contain a free-lance section which normally sets forth a schedule of fees covering per-program performance. The NLRB has normally included free-lance employees in station bargaining units of full-time staff performers as long as there is a reasonable degree of continuity of the part-time employment. ${ }^{30}$

${ }^{28}$ Radio Station KHQ and KHQ-TV, III N.L.R.B. 874 (1955), and cases cited therein.

${ }^{20}$ Miami Valley Broadcasting Corp., 70 N.L.R.B. I015 (1946); WCAU Broadcasting Co., 72 N.L.R.B. 537 (1947); Delaware Broadcasting Company, 82 N.L.R.B. 727 (1949); Westchester Broadeasting Corp., 93 N.L.R.B. 1346 (1951); Neptune Broadcasting Company, 94 N.L.R.B. 1052 (1951); KHMO, Radio Station, I4-RC-r481, January r8, 1952; Pennsylvania Broadcasting Company, 100 N.L.R.B. 254 (1952); Triangle Publications, Inc., II5 N.L.R.B. 94I (I956). But of. Guard Publishing Company d/b/a Radio Station KERG, 36-RC-627, July 16 , 195I, where a news commentator and a farm director were rather casually excluded from a unit of announcer-control operators and technicians.

${ }^{30}$ KMOX Broadcasting Station, ro N.L.R.B. 479 (1938) (an early decision where staff and free- 


\section{Full-time Employees Who Serve as Announcers on a Part-time Basis}

This has been a substantial problem for the unions, management, and, where it has been presented, for the Board. Management has a natural interest in getting maximum voice variety by using all employees who have performing talent. For example, a secretary may do an occasional commercial announcement, or a salesman may handle a sportscast. AFTRA has, in its contracts, generally tried to restrict the use of such people, largely because of a desire to keep all commercial work which might carry fees for regular announcers. The NLRB has taken the position that such employees will be included in the bargaining unit if their announcing duties are such as to give them a continuing interest in the employment relationship. ${ }^{31}$ A complicated variation of this problem has arisen in connection with musicians who, within the confines of a single program, mix musical performance and ad-lib commentary. The cases suggest that these employees will normally be treated as musicians, at least for bargaining purposes, although the matter is not entirely clear. ${ }^{\mathbf{3 2}}$

\section{Performers not Working as Employees of the Station or Network}

With some free-lance performers, there is a real question as to whether they are employees or independent contractors and, if employees, whether they are employed by the station or network, on the one hand, or an advertising agency or sponsor, on the other. Despite company assertions in a substantial number of cases, the Board has generally held that free-lance performers are employees rather than independent contractors. ${ }^{33}$ At the station level, the broadcaster has almost always been labeled as the employer rather than an agency or a sponsor. ${ }^{34}$

lancers were placed in the same bargaining unit); Southern Tier Radio Service, Inc., I07 N.L.R.B. 216 (195I). (a performer included in the unit who handled a I5-minute once-a-week show); WAPO Broadcasting, Inc., ro-RC-2249, June, I953; WTAR Radio Corp., I00 N.L.R.B. 250 (1952).

${ }^{81}$ Prior to $195 \mathrm{I}$, such employees were included in the bargaining unit but were not permitted to vote unless $50 \%$ or more of their time was spent in performing work. See, for example, Delaware Broadcasting Co., 82 N.L.R.B. 727 (1949). The rule was reversed in Ocala Star Banner, 97 N.L.R.B. $3^{84}$ (1951), where the usual rule in regard to voting eligibility of part-time employees was extended to cover this situation. The inclusion of such employees in the voting unit does not presumably give the union the right to bargain for their non-performing activities.

${ }^{33}$ In an early decision, Miami Valley Broadcasting Company, 70 N.L.R.B. 1015 (1946), the Board, with the open acquiescence of the Musicians' Union, included in an announcer bargaining unit a musical director who played an instrument and talked during the course of a single program. A much more recent case, Westinghouse Radio Stations, Inc., r07 N.L.R.B. I407 (r954), excluded from an announcer bargaining unit two ad-libbing instrumentalists. The stage was set for a final resolution of the problem at the network level, where it has been most acute. In a proceeding in which the American Broadcasting Company filed a motion for clarification on the particular point, the record was opened, extensive hearings were held on the facts, then the Board somewhat belatedly decided that a motion to clarify was not the appropriate procedural mechanism and thus refused to pass on the matter. American Broadcasting Co., Inc., II2 N.L.R.B. 605 (1955).

${ }^{38}$ An exception was found in Emil Denemark, Inc., 96 N.L.R.B. I087 (I95x) where several announcers who were described as acting in the capacity of time brokers were labeled as independent contractors and excluded from a staff bargaining unit.

84 WAPA, 24-RC-24I, November 19, 195I. But sponsors were held to be employers of individual performers in L. B. Wilson, Inc., 54 N.L.R.B. 125 (1943) and WTAR Radio Corp., 100 N.L.R.B. 250 (1952). 


\section{Program Department Supervisors}

From a bargaining unit point of view, supervisory problems in broadcasting are not substantially different from those which exist in other industries. The basic statutory definition contained in section two of the National Labor Relations Act applies. Reduced to its simplest terms, a statutory supervisor is one who has at least the authority effectively to recommend changes in the status of subordinate employees or responsibly to direct their work. Employees who fit this definition must be excluded by the Board from bargaining units, although they are sometimes included in contract units. ${ }^{35}$

\section{B. Technician Bargaining Units}

As with announcers, the pattern for technician bargaining units in broadcasting was set during the ' 30 's by collective bargaining agreements. The first union in the field, the IBEW, was interested primarily in representing technicians and not other broadcast employees. In the typical station, as in the networks, technicians normally formed an identifiable departmental as well as an identifiable skill unit. ${ }^{38}$ Unit problems in collective bargaining and before the Board have primarily involved either combination work situations or the status of fringe groups working closely with technicians. For example, difficulty has arisen in the placement of announcers who handled the control board as part of their regular duties. This is the dominant pattern of operation in small-market stations, and is increasingly the pattern in the medium-size and larger stations. The present rule seems to be that announcercontrol operators will be excluded from a unit of technicians unless the petitioning union wants to include both groups in a single operational unit. ${ }^{37}$

The application of the supervisor rules to technicians in broadcasting has created no unusual problems, either in radio or in television. As might have been expected,

${ }^{36}$ Program directors have been excluded as supervisors in the following cases: WLEU Broadcasting Corp., 6-RC-8II, September I8, I95I; Neptune Broadeasting Co., 94 N.L.R.B. I052 (195r); KHMO, I4-RC-I48I, January 18, 1952; WWEZ Radio Inc., 15-RC-389 and 390, November 8, 1950; Delaware Broadcasting Co., 82 N.L.R.B. 727 (I949); and Atlanta Journal Co., 59 N.L.R.B. 673 (1944). A program director was found not to be a supervisor in Ridson, Inc., 18-RC-747, Sept. 20, 1950 . In Badger Broadcasting Co., $13-R C-r 60 r$, December 29, r950, and WAPO Broadcasting, Inc., ro-RC-2249, June r953, a news director and a program director, respectively, were excluded from announcer bargaining units because on the facts of the two cases, they were regarded as being closely allicd to management. This is a basis of exclusion which is rarely used.

${ }^{38}$ Several early Board decisions set up separate units of transmitter technicians, but in these cases, the studio technicians handled some announcing functions. Inter-City Advertising Co., 55 N.L.R.B. 1415 (1944); Colorado Radio Corp., 55 N.L.R.B. 423 (r944); Ashbacker Radio Corp., 60 N.L.R.B. 1003 (1945). From I946 onward, the Board seems to have followed a consistent course by placing transmitter and studio technicians in the same bargaining unit even where the union had filed for separate units. Atlanta Journal Co., 7o N.L.R.B. Ix68 (1946); Great Trails Broadcasting Co., 73 N.L.R.B. 396 (1947); Joe V. Williams, Jr. d/b/a WDXB Broadcasting Station, 85 N.L.R.B. 752 (1949).

${ }^{37}$ All Oklahoma Broadcasting Co., 16-RC-861, January 24, I952; Radio Station KHQ and KHQ-TV, III N.L.R.B. 874 (1955). Earlier small stations cases in which announcer-control operators were included with technicians despite the wishes of the petitioning union seemed to have been at least implicitly overruled. Among the earlier single-unit decisions are Louis G. Baltimorc, 57 N.L.R.B. I6r I (1944); Western Gateway Broadcasting Corp., 77 N.L.R.B. 49 (1948); and Associated Electronics Enterprises, Inc., 80 N.L.R.B. 295 (1948). 
chief engineers have normally, but not always, been excluded as supervisors. ${ }^{38}$ Assistant chief engineers have been included in nonsupervisory bargaining units of technicians, although the cases have involved small stations. ${ }^{39}$ Other supervisory technicians have been placed both inside and outside, depending on local facts. ${ }^{40}$

Television has, for the most part, followed the radio technical bargaining unit pattern. Most TV stations started as companions to radio stations operated by the same interests in the same market. Where a collective bargaining contract had covered radio technicians, it was normally extended by agreement to cover TV technicians as well. The NLRB has recognized this pattern and in a number of decisions has stated that normally radio and TV technicians, where employed by the same organization, will be included in a single bargaining unit. ${ }^{41}$

Another problem created by TV is the composition of an appropriate bargaining unit where the operation of studio technicial equipment is handled by production department personnel rather than technicians. The Board has generally taken the position that the employer's organization of his business will be controlling in regard to the placement of employees who operate technical equipment either as technicians or as production department employees. ${ }^{42}$

${ }^{38}$ In the following cases, chief engineers have been excluded from the technical bargaining units: Inter-City Advertising Co., 55 N.L.R.B. 1415 (1944); The Columbus Broadeasting Co., Inc., 56 N.L.R.B. II82 (1944); Ashbacker Radio Corp., 60 N.L.R.B. I003 (1945); WSPR, Inc., 60 N.L.R.B. 1351 (1945); King Trendle Broadcasting Corp., 74 N.L.R.B. 926 (r947); Tri-Cities Broadcasting Co., 74 N.L.R.B. 1 ro7 (1947). The chief was included in the bargaining unit in Louis G. Baltimore, 57 N.L.R.B. I6II (I944); Leon Wyszatycki d/b/a Greater Erie Broadcasting Corp., 92 N.L.R.B. 270 (r950) (containing a particularly good discussion of the supervisory problem as applied to a small station chicf engineer); Cannon System, Ltd., 2I-RC-I980, August 2, 195I; Cecil Roberts d/b/a Radio Station KCLO, I7-RC-1435, November 17, 1952.

${ }^{30}$ Middlesex Broadcasting Corp., 87 N.L.R.B. 1567 (1950); Presque Isle Broadcasting Co., 6-RC-654, February 6, 195I; and Arkansas Radio and Equipment Co., 32-RC-558, October 29, 1952.

${ }^{10}$ Subordinate technical supervisors were excluded in Great Trails Broadcasting Co., 73 N.L.R.B. 396 (r947); W. Albert Lee d/b/a Radio Station KLEE, 39-RC-r22, November 14, 1949; Kennedy Broadcasting Co., 96 N.L.R.B. 354 (195I); Mt. Mansfield TV, Inc., I-RC-4599, October 4, 1956; Arkansas Radio and Equipment Co., II5 N.L.R.B. 742 (1956); Scripps-Howard Radio, Inc., 93 N.L.R.B. I095 (I95I). Subordinate technical supervisors were included in Wodaam Corp., 83 N.L.R.B. 335 (I949); Central Florida Broadcasting, 94 N.L.R.B. 473 (195I); Leon Wyszatycki d/b/a Greater Erie Broadcasting Co., 92 N.L.R.B. 270 (I950); Crosley Broadcasting of Atlanta, I06 N.L.R.B. 795 (I953); The Fort Industry Co., 88 N.L.R.B. 527 (1950); Meredith Engineering Co., r03 N.L.R.B. 807 (1953). In Muscle Shoals Broadcasting Co., 74 N.L.R.B. I71 (I947), some technical supervisors were included in the unit and some excluded.

"Scripps-Howard Radio, Inc., 93 N.L.R.B. 1095 (I95I); Florida Broadcasting Co., 93 N.L.R.B. 1568 (195I); The Fort Industry Co., 88 N.L.R.B. 527 (1950). In one case, however, the Board did permit newly-employed TV technicians to vote separately on the theory that, while they could be joined with the radio technicians into a single unit, they should bave an opportunity to independently express their wishes on unionization. Arkansas Radio \& Equipment Co., II5 N.L.R.B. 742 (1956).

'This issue arose because the technicians' unions, particularly in the larger markets, were accustomed to broad jurisdictional coverage, and when television was added, the same philosophy was applied. The larger stations went along with this, either because it made sense operationally or because it was the line of least resistance. Without a prior history of bargaining, some TV stations were set up on a basis granting to production department employees the operation of studio technical equipment such as cameras and mike booms. Before the Board, in such cases, the technicians' unions argued that the unit should be based on their traditional broadcasting jurisdiction-that is, the operation and maintenance of all technical equipment. Rejecting this contention, the Board looked to the pattern of operation which the employer had set up to handle the work. Where the operation of cameras and mike booms, for example, 
The status of projectionists and lighting technicians has also created some controversy. Early efforts by the IATSE, which represents many projectionists in the motion picture theatre industry, to split off TV projectionists from TV technicians were rejected by the Board. ${ }^{43}$ Normally, projectionists will be treated as technicians and part of the technician bargaining unit unless they have been set up as part of the production department. Lighting technicians have generally been held to be production employees, not electronic technicians. ${ }^{44}$

\section{TV Production Employees}

Television brought for the first time to station broadcasting the employment of a substantial number of production employees such as floormen, artists, film editors, stagehands, photographers, and directors. In the large-market TV stations, these employees are represented in a variety of bargaining-unit patterns. In the medium and smaller markets, TV production employees are, for the most part, unorganized. As early as 1949 , the Board noted that either a single unit of technicians and production employees together, or separate units of each, might be appropriate-thereby recognizing the right of production employees to express their wishes independently of technicians. ${ }^{45}$ In effect, the Board was saying, as it had done in other industries where unit considerations were closely balanced between two alternative unit choices, that the wishes of the employees themselves would determine the appropriate unit. ${ }^{46}$

Single units of technicians and production department employees have been held appropriate when agreed to by the petitioning union and the company. ${ }^{47}$ Announcers were included in a unit of production employees, with the apparent agreemenit of the company and the petitioning unions, in one case; ${ }^{48}$ while a unit of all nonperforming program department employees were held appropriate in another. ${ }^{40}$

Generally, the Board will not accept a partial unit of production department

is handled by production department employees, they will normally be included in a unit of technicians. Empire Coil -Co., rớ6 N.L.R.B. 1069 (1953); WTTV, x15 N.L.R.B. 535 (1956).

${ }^{13}$ KMMTR Radio Corp., 85 N.L.R.B. 99 (1949); Radio Station WLAV, 7-RC-595, December 30, 1949; The Fort Industry Co., 88 N.L.R.B. 527 (1950); American Broadcasting Co., Inc., 92 N.L.R.B. 995 (1950); Columbia Broadcasting System, Inc., ro8 N.L.R.B. 1468 (1954).

" KMTR Radio Corp., 85 N.L.R.B. 99 (1949); National Broadcasting Co., 95 N.L.R.B. 1334 (195I); Don Lee Broadcasting System, 98 N.L.R.B. 453 (1952). But cf. KTTV, Inc., 97 N.L.R.B. 1477 (1952) where lighting technicians were included in a unit of technicians. In these "lighting" decisions involving bargaining units, the Board gets perilously close to resolving questions of work jurisdiction.

${ }^{45}$ KMTR Radio Corp., 85 N.L.R.B. 99 (1949); WCAU Broadcasting Co., Inc., 72 N.L.R.B. 537 (1947); Empire Coil Co., Inc., ro6 N.L.R.B. ro69 (1953); Midwest Radio-Television, Inc., III N.L.R.B. 337 (1955); Bartell TV Corp., 13-RC-5280, April 3, 1957. But of. Mcredith Enginecring Co., 103 N.L.R.B. 807 (1953) where the Board, despite the wishes of one of two unions involved, refused to include facilities department employees in a unit of technicians or to let their wishes determine the scope of the unit.

${ }^{10}$ Globe Machine and Stamping Co., 3 N.L.R.B. 294 (1937).

${ }^{47}$ Southern Tier Radio and Television Equipment Co., 107 N.L.R.B. 216 (1953).

${ }^{48}$ Erie Dispatch, Inc., 6-RC-x156, Dec. 8, 1952.

${ }^{49}$ National Broadcasting Co., Inc., 95 N.L.R.B. 544 (195x). 
employees. ${ }^{50}$ All nonsupervisory employees in a production department will normally be included in a single-voting unit. An exception to this general rule exists where a limited group of production department employees have special interests or skills in common. ${ }^{51}$

Of the specific classifications of production department employees, directors have uniformly been held to be supervisors in NLRB decisions, although they are covered by a number of contracts at the station level. ${ }^{52}$ Assistant directors have also been held to be supervisors. ${ }^{\text {b3 }}$ Of course, in each case, the Board applies the customary statutory definition to the particular facts. Artists have been denied professional status and thus have been included in voting units of production department employees..$^{54}$ Nor have artists been accorded craft status as the term is used in NLRB craft severance decisions. ${ }^{55}$ IATSE has several units of film department employees in the network origination centers of New York, Chicago, and Los Angeles. Some technician contracts include them in other markets. The NLRB has touched on the matter only in one decision, where film department employees were included in an over-all production department unit. ${ }^{56}$

\section{III}

\section{The Climate of Bargaining}

The climate of bargaining relates to the environment in which the substantive issues of wages, hours, and working conditions are raised and resolved. Climate is concerned not so much with what happens at the bargaining table, but rather with how and why it happens-not so much with the fact of $15 \$$ an hour increase, but rather why the two parties made it $15 \%$ rather than $5 \phi$ or $50 \%$. The "how" and the "why" of bargaining are not easy to determine for an individual company, much less an industry. A final answer for broadcasting would call for a carefully-planned on-location investigation-both sociological and economic in nature. Lacking such original research, something can be said about the subject on the basis of general observations, based on first-hand experience, of the industry's labor relations over a period of eight years.

The basic factors molding broadcasting labor relations-the nature of the product,

${ }^{60}$ Summit Radio Corp., 8-RC-2189, June I, 1954; Hearst Radio Inc., 5-RC-867, Oct. r8, r95r.

${ }^{51}$ Pulitzer Publishing Co., ror N.L.R.B. I005 (1952), where four stagehands with craft experience were designated as an appropriate unit; Scripps-Howard Radio, Inc., 9-RC-2796, Aug. 14, 1956, where . a unit of floormen and property men was held to be appropriate.

${ }^{53}$ American Broadcasting Co., Inc., 94 N.L.R.B. 100 (x95 ); American Broadcasting Co., Inc., 93 N.L.R.B. I410 (195I); KRLD, I6-RC-1353, Nov. 30, 1953; Westinghouse Broadcasting Co., Inc., I-RC-3.473, April 6, I954; Scripps-Howard Radio, Inc., 9-RC-2796, August 14, 1956.

${ }^{23}$ WCAU, Inc., 4-RC-828, March 29, x95I; WTOP, Inc., II5 N.L.R.B. 758 (I956); Mt. Mansfield TV, Inc., I-RC-4599, Oct. 4, 1956.

${ }^{5}$ National Broadcasting Co., Inc., 95 N.L.R.B. 544 (r95I); WKY Radiophone Co., I6-RC-r324, August 21, 1953. Section 2(12) of the Taft-Hartley Act defines the term professional employee, and $\$$ 9(b) precludes the Board from setting up a unit including both professional and other employees unless a majority of the professional employees have voted for inclusion in the unit.

"5 WBAL Division-The Hearst Corp., 115 N.L.R.B. 501 (1956).

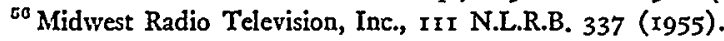


the structure of the industry and the jobs-determine the climate of bargaining, both at the bargaining table and in the administration of the contract. Thus formed, the climate is suggested by such matters as the identity of the negotiators, typical issues, and methods of resolution; it is dominated by the relative bargaining strength of the parties.

Network negotiations are conducted, for the most part, by professionals-labor relations experts for the companies, and full-time staff officials (sometimes with rankand-file committee help) for the unions. ${ }^{57}$ Station negotiations are less formal and less professional. The general manager usually does the talking for the company, occasionally with the help of local legal counsel. Some of the largest stations will use subordinate staff officials, such as a business manager, to conduct most of the negotiations. Unions at the station level are usually represented in the big markets by a full-time local official, and elsewhere by a regional or national field agent. In either case, bargaining committees of local employees are customarily involved. The degree of involvement varies substantially from case to case. As has been noted before, almost all bargaining at the station level is on an individual station basis. ${ }^{58}$ The networks jointly negotiate some agreements with certain unions.

At the station level, the nonprofessional status of the negotiators on the company side of the table has probably been a source of some advantage to the unions. This is not an uncommon situation where small companies are involved and is sometimes cited as one good reason for multiple-employer bargaining where small companies competing within one community bargain with the same union. Even where a station manager has a natural aptitude for bargaining, his lack of expertise in the field, as well as his lack of full-time concentration on bargaining problems, may be handicaps to effective bargaining from the company's point of view.

There are no statistics indicating the "deadlock" issues most frequently arising in broadcasting. General industry experience, however, suggests that two basic issues have predominated: money, and job or work protection. The first has received major emphasis during the last fifteen years of bargaining in broadcasting; the second, always important, is now receiving increasing attention. Broadcasting unions have traditionally concentrated on wages, and, as will be documented in a later section, the results of their efforts have been substantial.

While wages are still high on the bargaining list, job or work protection has been steadily coming to the fore. When the basic broadcasting contracts were written in the late ' 30 's and the early ' 40 's, craft concepts of work control were established. These concepts generally fitted normal methods of operation, particularly at the larger stations and in the networks where union organization first started. That they occasionally, and perhaps increasingly, intruded on manage-

${ }^{\mathrm{Br}}$ Five years ago, most industry contracts were one-year agreements, with automatic renewal clauses. Today, a majority of the agreements are for two years, with a scattcring of longer-term agreements.

${ }^{58}$ In several West Coast markets, there is some multi-employer bargaining covcring certain groups of stations. Some believe that the failure of stations to get together for bargaining purposes on a market basis has been a significant factor in union success at the bargaining table. 
ment's desire for flexible operation was annoying, but not catastrophic-until improved technology made some changes obvious and declining profits in radio made them necessary. Thus, it has been a matter of slowly and sometimes painfully modifying old ways of doing business on a contract-by-contract basis. Sometimes the changes are slight, such as letting announcers operate portable tape recorders. At other times, they are drastic, such as when announcers take over the control board, thereby cutting a technician bargaining unit in half, or when equipment has been set up to operate by remote control, with a similar or even more drastic effect on the bargaining unit. The high level of demand for electronic technicians in TV and elsewhere during this adjustment period, which has been going on since about I950 and is not over yet, has somewhat reduced the severity of the problem. Still, for the unions involved, the political problems have been substantial. To their credit, it should be said that, by and large, they have not, at least at the national level, flatly opposed such changes, but have rather tried to control the impact-an enlightened attitude not always reflected in local negotiations. The problems in radio have made everybody conscious, even overly-conscious, of the issue. The concern, therefore, readily finds its way into TV negotiations, where similar problems are already beginning to crop up. The reasons giving rise to the issue in radio-improved technology and declining profits-are likely to accelerate the problem in TV during the next five years.

A drive for the shorter workweek in broadcasting has not yet begun in earnest, but the demand has appeared in a number of important negotiations in the past year. The possibility of a reduction in job opportunities is an obvious impetus for a drive for shorter hours. The forty-hour workweek is still standard in broadcasting industry agreements, although some will argue that there are a few cracks in the dike through compromises on lunch-period time allotments.

Fringe benefits of the usual variety have received secondary, but consistent, emphasis in broadcasting negotiations. Longer vacations, more holidays, increased premium rates under specific circumstances are almost always tossed into the hopper. This steady pressure has resulted in continual improvement from the union's point of view, but these issues seldom lead to deadlocks. Pensions at the station level have been of little or no importance. At the network level, AFTRA's fight for a pension and welfare plan covering network performers met with success in the national negotiations conducted in the fall of 1954 . The so-called guaranteed annual wage, popular in other negotiations, has meant little in broadcasting because employment does not vary appreciably with changes in sales as in most industries.

One issue that is important to the unions is union security. Before the TaftHartley Act, the closed shop was normal in industry contracts, just as the union shop is now, except in those states with right-to-work laws. Only rarely have broadcasting companies made a fight on this issue, which the unions regard as crucial because of the small bargaining units and relatively high turnover of people. 
Most broadcasting negotiations are resolved without resort to a strike. A rough estimate places the number of strikes at one for every one hundred negotiations, there being between 400 and $45^{\circ}$ negotiations per year in broadcasting. This is probably a reasonable estimate over a ten-year period. Within the past two years, the ratio is undoubtedly somewhat higher. Generally, the parties work out their problems without outside help. Federal and state mediators have been used only occasionally in the past. Their use may be increasing. Arbitration of contract terms is rare in the industry. Only one or two stations are now committed to it. There are those who feel that, in certain segments of the industry where there is substantial inequality of bargaining power, it is a technique calling for more careful consideration.

The hard core of collective bargaining is force or the threat of force: the ability and willingness to impose economic injury, on the one hand, and the ability and willingness to withstand it, on the other. This equation determines the relative bargaining strength of the parties. These may seem like harsh words, particularly to those who like to talk about collective collaboration rather than collective bargaining. Collaboration there may be up to a point, yet when words have failed, and even before that time, the power relationship comes into play. And this is the result of the collective bargaining mechanism, not just an occasional result of faulty functioning. In our society, we not only accept it, but encourage it as a means for determining wages, hours, and working conditions of employment in a competitive economy. It is premised on the belief that the economic incentives for settlements-loss of wages, on the one hand, and the loss of present or future profits, on the other-constitute, whether actually used or not, the best method for the voluntary resolution of collective bargaining disputes. ${ }^{59}$ This view of life does not mean that intelligence, understanding, and patience won't reduce the situations in which force is actually used. Obviously they will. They may even prevent the use of force for long periods of time in certain relationships. But they cannot eliminate the possibility of force as the basic element without changing the essential nature of collective bargaining as we know it in the United States.

A union in broadcasting has five major sources of strike pressure:

I. Complete or Partial Interference with the Operation of the Facility by the Re: fusal of Unionized Employees and Their Sympathizers to Perform Work

This is the traditional strike weapon. It is not as effective in broadcasting as in industries where bargaining units are large or essential skills are difficult to replace, even on a temporary basis. Indeed, recent experience tends to indicate that most stations can be kept on the air, at least for limited periods of time, with the use of supervisory and temporary employees, without substantial loss of quantity or quality

${ }^{50}$ Other possible methods for determining conditions of employment are unilateral employer action, arbitration, government edict, or even unilateral employee action with employer acquiescence. Voluntary consent of the parties not to use force, sometimes described as a fifth method, while theoretically "conceivable, is in reality unilateral action by one side or the other with the advice and consent of the opposite party. 
of service. This fact has long been obvious where announcers were concerned, but has only recently become evident where technicians are involved. At the networks, a different situation exists, particularly in television. A walkout of technicians would at least disrupt service substantially. The degree of disruption is likely to depend, in large part, on network ability to keep the facility in operation with nonunion supervisors and other personnel-a much more difficult task than at the station level. With performers, too, the network problem is much more difficult. The essence of many programs is the performer. His absence makes an immediate difference, which is recognized all over the country in literally millions of homes. In station bargaining, the ability of many stations to stay in operation despite a strike has significance in terms of the essential structure of collective bargaining. While bargaining power is seldom equal, a radical and recognized imbalance in the power relationship cuts at the heart of the bargaining process.

\section{Interference with the Supply of Materials or Services}

Aside from national network service, which involves almost all TV stations but only 40.1 per cent of the radio stations, broadcasters are free of regular delivery problems-a strategic fact of some importance. The product is delivered directly to the customer via the airwaves; materials needed, with the noted exception of network service, are, in large part, easily available from a variety of sources. The networks, while not dependent upon suppliers of materials or component parts to the same extent as the typical manufacturing plant, are more dependent on the services of employees of other employers than are the stations.

A network-affiliated station, particularly in TV, would be seriously hurt if it lost its network service. For example, if network technicians in New York could refuse to furnish programs to a station in Detroit because of a local dispute involving that station, this would be a substantial factor in the bargaining relationship. The secondary boycott section of the Taft-Hartley Act generally prevents this type of secondary pressure. ${ }^{60}$

\section{Interference with the Operation of an Allied Business}

The newspaper-owned station has always worried about a picket line around the newspaper plant which, if the mechanical unions refuse to cross the line, will normally cause a shut-down-a situation which most publishers are not willing to face. This fear has been a decisive factor over a period of years in some key broadcasting negotiations. There have been relatively few strikes involving newspaperowned stations. Even when they have occurred, the mechanical unions have not always refused to cross the broadcasting picket lines. A related problem involves multiple-station groups. As has already been noted, bargaining is almost always on an individual station basis, with the only significant exception being the company-wide contracts between the networks and the technician unions. The facts of separate

${ }^{\circ 0}$ Section $8(\mathrm{~b})(4)$ of the Taft-Hartley Act and its application to broadcasting will be discussed in detail in a later section. 
bargaining units, separate contracts, and geographical distance have kept disputes localized, even where the same union represents more than one unit in a multiplestation group. On the other hand, the multiple-station group has somewhat increased bargaining power over a singly-owned station because of greater resources, particularly supervisory manpower.

\section{Pressure on Sponsors to Withdraw Their Patronage from the Struck Facility}

While this is third-party pressure and clearly a type of secondary boycott, it is. not subject to the existing Taft-Hartley prohibition as long as there is no inducement of the employees of the sponsor to refuse to perform work. The tactic has been used in most recent broadcasting industry strikes. Its efficacy has varied from case to case, in part dependent on the union climate in the community. With a few exceptions, it has not been decisive. Most sponsors resist the pressure. On the other hand, the tactic has had sufficient effect to have been a factor in a number of strike settlements over the past three years.

\section{Community Pressure}

It might be thought that community pressure would be an important bargainingtable fact in a business like broadcasting. Experience does not bear this out. Union appeals to the community, usually trying to show the unfair nature of the company's position, have apparently had no great effect. Even disruption or temporary loss of service is not likely to bring about a substantial community reaction, unless the struck facility is providing the only service available in the area.

So much for the strike tactics individually. Taken together, they give a picture of the sources of union strength as well as suggest their limitations. They relate to a union's ability to inflict economic injury and to a company's ability to withstand it.

But ability in this sense is not the only factor. Willingness is an equally important factor. Unions, obviously, do not strike every time their demands are rejected even where they have the probable power to insure victory. Conversely, employers do not always hold firm or press their own demands where a strike is likely to: cause them little damage. Willingness to strike on the union's side involves a whole host of factors, such as the importance of demands, chances of winning, solidarity of the membership, their economic position, and the political position of union leaders. Company willingness to take a strike depends on the nature of the demands, financial condition, the competitive picture, and the chances of successfully withstanding the economic pressure. Beyond the specifics, it can probably be stated as a general truth that in most situations, neither side is eager for a shut-down. A strike is a drastic step. It is economic warfare. Most intelligent people do not undertake it lightly. Moreover, a strike involves risks for the organization (whether company or union) and for those who have the responsibility for running it-risks which cannot be exactly measured in advance. 
Given this general framework for bargaining in broadcasting, what have been: the results? Ultimately, the results are found in two places: the contract clauses and in the day-to-day relationship between the parties. Some of the more important contract clauses will be discussed in detail in the following section. To generalize about contracts as a whole is difficult because of a lack of readily available norms. However, at the risk of oversimplification, it can probably be said that unions in broadcasting have made very substantial dollar gains for their members, but are having increasing difficulty in the area of job protection. The gains, particularly in. wages, have resulted from a variety of circumstances, with two being crucial: high profit in important segments of the industry, and lack, or imagined lack, of employer ability to withstand economic pressure in certain key negotiations. Lack of success. in the area of job protection (and this lack of success is a relatively recent development) comes also from a variety of conditions. Most important are developing. technology, declining profits in radio, and a growing awareness on the part of broadcast management of the power relationship. This last factor is likely to becomeincreasingly important in the bargaining-table aspects of broadcasting labor relations.

Contract administration-the day-to-day aspects of collective bargaining-is much more complicated and important in many industries than it is in broadcasting at thestation level. With small bargaining units and clearly defined work patterns, sources. of friction are few. Grievances are rare, and arbitrations rarer yet. Only at a relatively few, and normally the bigger, stations are there problems. Most of these probably arise from personality clashes rather than from genuine confusion over contract interpretation. Given any sort of reasonable human relations environment, contract administration at the typical station should be relatively easy to handle.

A different situation exists at the networks, primarily because of larger bargaining units and a much more complicated production environment. Indeed, the production. job at the networks is much less routinized than at the typical manufacturing plant. Constant and expert attention is necessary to keep the machine running smoothly.

\section{IV}

\section{The Collective Bargaining Contract}

The recorded story of collective bargaining is the labor contract. In this instrument, the parties set down the terms and conditions covering their relationship. Broadcasting agreements are, in general outline, similar to those found in many segments of American industry. ${ }^{61}$ They cover the following major aspects of the employment relationship: wages and fringe benefits, job protection, work rules, hours. and working conditions. Of the other clauses often found, most can be fitted under

${ }^{o x}$ An exception exists in regard to certain network contracts with unions representing creative employces. For example, the network codes with AFTRA are substantially different in set-up and in content from the typical industrial agreement. The free-lance performers' codes found in some of the larger markets follow the network code pattern. While these agreements relate to the three basics of wages, hours, and working conditions, the employment relationship is so different from that normally found that the agreements seem quite unrelated to the typical labor relations contract. 
the general heading of contract administration. Only the two most important aspects, wages and fringes, and job protection, will be discussed in any detail in this article. Before discussing them, a brief look at some of the other categories will be worthwhile.

The term "work rules" is not precise. It is used here to reference those contract clauses which relate to the individual's job and its performance-not so much to what he shall do, but to how he shall do it, and how he shall conduct himself while on the job. The most important work rules to the employee and to management are those relating to termination, particularly discharge. Almost every broadcasting agreement has a discharge clause. The usual wording permits discharge for cause. Cause is sometimes spelled out in detail. Arbitration of discharges is almost always permitted. With technicians, this approach has caused no problems; with announcers it has.

Personality obsolescence in a particular environment is an important fact for announcers. A change of voice in radio or a new face on TV may be desirable long before purely physical considerations affect a man's ability to perform. With freelance performers, the problem takes care of itself. They don't get work when their popularity fades. Staff announcers, on the other hand, may have to be terminated unless they resign. The usual discharge clause is inadequate to handle the situation. Management pressure to get more flexibility has met with limited success through clauses found in a few agreements which define cause to include unsuitability to the station's program requirements. General acceptance and reasonable interpretation of such language would obviously go a long way towards solving the problem.

Layoff provisions have received nowhere near the emphasis in broadcasting that they do in many industries, where variations in production volume have a recurring and substantial impact on employment. Layoffs are normally according to length of service, with only a handful of industry agreements permitting a consideration of ability. The seniority unit for layoff purposes is normally the contract unit. Other work rules, such as those relating to the maintenance of discipline, are of little or no importance in the typical broadcasting industry agreement.

Clauses on hours and working conditions contain little that is unique or even unusual. As noted earlier, the forty-hour week is the almost uniform practice. The semi-continuous nature of the business gives rise to some scheduling complications, which are often reflected in rather elaborate schedule change provisions. Working conditions in broadcasting have created no unusual problems, aside from those created by the remote location of a few transmitters.

Contract administration can be broadly defined to cover a multitude of seemingly unrelated clauses. The provisions which first come to mind are those relating to the settlement of disputes arising during the term of the agreement: the grievance and arbitration machinery. Almost all broadcasting agreements have such clauses. They follow the usual pattern with only one significant variation. A good many AFTRA contracts permit the use of the grievance and arbitration machinery for the resolution 
of any dispute arising during the term of the contract. Even disputes regarding individual above-scale agreements may be submitted to arbitration. The other side of the coin of the dispute settlement problem is the no-strike, no-lock-out clause, which is found in almost all industry agreements. The language of these clauses varies widely, from a rather simple and direct prohibition against strikes and lock-outs to rather elaborate provisions qualifying and limiting union responsibility for stoppages. ${ }^{22}$

\section{A. Wages and Fringe Benefits}

The casual observer of wages in broadcasting finds a bewildering array of both unusually large differences in pay for the same jobs and unique, or at least, atypical compensation practices. Close inspection begins to reveal certain patterns of consistency and explanations of diversity. Much of the rationale is to be found in the fundamental economic structure of the business.

The level of wages in both union and nonunion segments of broadcasting is high. This flat statement is based on the fact that, within a particular labor market, wages for many specific occupations in broadcasting are generally substantially above those for the same jobs, or for jobs with roughly the same degree of skill, responsibility, and effort found in other industries. ${ }^{63}$ Unfortunately, the lack of comprehensive, reliable wage data in small cities makes a complete documentation impossible. In markets of over roo,000 population, it is not uncommon to find wage differentials on some broadcasting jobs in favor of broadcasting of fifty per cent. This is especially true for the job of technician, which has its counterpart in both radio-TV repair shops and in electronic manufacturing. ${ }^{64}$ Detailed study of a large eastern market revealed, for example, broadcast technicians at the unionized stations earning from $\$ 130-\$ 170$ per week. This was in sharp contrast to the less than $\$ 100$ paid in this same labor market for technicians with comparable (or greater) skills in both radio-TV repair and manufacturing. ${ }^{65}$

Of all the factors which may account for high wages in broadcasting, none is more important than the profitability which, with some exceptions, has characterized the industry. The direct result of financial well-being has been an ability and, probably in some cases, a willingness ${ }^{66}$ to pay wages substantially higher than would be needed to recruit and maintain an efficient work force.

${ }^{03}$ Strikes during a contract term are extremely rare in broadcasting, due in part no doubt to the fact that contract administration problems are relatively simple. Only the networks have been bothered by quickie or "unauthorized" stoppages.

${ }^{03}$ Based on comparisons of occupational data between annual wage surveys and compilations of contract scales by the NARTB and community, industry, and union-scale wage surveys by the United States. Department of Labor, Bureau of Labor Statistics.

ou See, e.g., U.S. Bureau of Labor Stattstics, Dep't of Labor, Bull. No. 1150, The Mobility of ELrctronic Technictans, 1940-52 (1954).

${ }^{08}$ Nonmonetary job elements, such as physical effort and working conditions, are almost invariably less onerous in broadcasting and, consequently, accentuate rather than compensate for, the monetary of wage-rate differential. Veterans' Administration, U.S. Buresu of Labor Statistics, Dep't of Labor, Employment Outlook in Skilled Electrical and Electronic Occupations 44-45 (VA. Pamphlet 7-9 I956).

${ }^{\circ}$ Lloyd G. ReYNolas, Structure of Labor MARKETS, 232, 233, 247, 248 (I95I). 
Where an industry has had an ability to pay relatively high wages, unions have at least the opportunity to make rapid and significant wage and fringe-benefit advances. When the reluctance of many stations to take a strike is added to financial well-being, it is not difficult to understand why wages in the unionized stations are high. But even in the larger nonunion part of the industry, the relative level of compensation is high. Among the causes have been shortages of electronic technical skills, especially in the earlier years of broadcasting, when the technology required relatively higher skills and when other industries utilizing electronic technicians were only beginning; the increasing realization of the direct contribution to the business made by performers; fear of unionization, especially in the medium and large markets; and the climate of financial prosperity which, among other things, tends to raise employer concepts of what constitutes a fair wage.

The most striking pattern of wages in broadcasting is the strong correlation between wage levels and the population size of the market in which a station is Jocated-the larger the market, the higher the wage. ${ }^{67}$ Precisely why this correlation exists is extremely speculative. One tentative answer is that historically in broadcasting profit margins have correlated generally with revenue size, which in turn correlates with market size. In other words, the ability to pay higher wages may be greater in the large stations in larger cities. Additional factors may be tighter supplies of labor, stronger unionization, higher standards of living, and perhaps some differences in job content, or at least in the job specifications used in the hiring process.

As in most industries, a North-South wage differential exists in broadcasting. ${ }^{08}$ When market size is taken into account, the regional differential is not particularly wide. This is especially true for some of the higher-skilled jobs which are in short supply in the South.

\section{r. Wages of Technicians}

Technicians' labor contracts in broadcasting have relatively simple wage clauses. Most agreements have only one grade of technician. Consequently, the wage scale generally covers a multiplicity of duties which job evaluation experts might consider as two or three or even four different jobs. ${ }^{69}$ Where the station is an AM-TV combination, the same wage scale generally covers all technicians, albeit the scale is usually higher than in competing stations which have a radio operation only. ${ }^{70}$

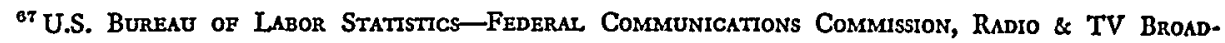
Casting IndUStry-Average Hours, Earnings, and EMployment 12 (1950); NARTB, 1955 RndioWages, Hours, Employment pt. 3, at 6; NARTB, r957 T'eleviston-Wages, Hours, Employment 44.

${ }^{88}$ See note 67 supra.

${ }^{\circ 9}$ Among the many jobs which "technician" often covers are the maintenance technician, transmitter technician, studio technician, cameraman, projectionist, and mike boom operator. Only in a few situations will one technician handle all of these tasks on a regular basis so that they might reasonably be considered as constituting one job. Nonunion stations frequently make use of more than one job title and one wage scale. A small minority of television contracts also so provide.

${ }^{70}$ Although some AM-TV stations do have integrated technical staffs, and although there are some added skills and responsibilities for a TV technician, the overriding explanation of higher wages in TV 
The wage scale typically includes a rate range, with a progression period of three to four years divided into annual or semi-annual steps. Movement through the range is by straight seniority. The spread of the range from minimum rate to maximum rate is frequently fifty per cent or more of the minimum-exceptionally wide when compared with ranges in other industries. ${ }^{\mathbf{7 1}}$ The effective range is somewhat reduced by the hiring of new employees above the minimum rate in accordance with the typical clause which credits past broadcasting experience with some seniority, and by the existence of tight labor markets.

Technicians' scales are expressed in weekly rather than hourly terms, with a forty-hour week as standard. Rates vary from a typical maximum of about $\$ 75$ per week in the smallest towns to $\$ 160$ in the largest metropolitan areas. Currently existing is a maximum of $\$ 170-\$ 175$ at the networks and the network-owned stations, where company-wide bargaining has established one uniform, nationwide rate range. Unlike most industries which employ rate ranges, the average technician rate within a particular station frequently approximates the maximum rate. This is due both to the use of seniority, with merit rarely considered, for progression within the range and the existence of abnormally low turnover, especially in the larger markets, where broadcast technicians' rates and working conditions are far superior to those prevailing for technicians with comparable skills in other industries.

\section{Wages of Announcers}

Of all the elements of labor relations which distinguish broadcasting from other industries, none is so striking as the method of compensating announcers. Weekly wage scales similar to those in technician contracts, but normally with a lower maximum rate, provide the basic wage. Here the similarity ends. For most performers, the basic wage is only a minimum guarantee, comparable to the minimums negotiated in' many European labor agreements.

In addition to the basic scale, announcers receive compensation-talent feesbased on some of the particular tasks they perform..$^{72}$ Although originating as a method to compensate for such unusual or irregular work assignments as "outof-stretch"73 work, the selection of specific announcers by advertisers, and the per-

for technicians (as well as for many other jobs) appears to be the greater profitability of TV operations-

- another example of the significance of the ability-to-pay principle as a determinant of the broadcast wage structure. During the past several years, in a number of important markets, separate AM and TV technician scales have been negotiated.

${ }^{72}$ There are indications that the concept of broad ranges was taken directly from another segment of the communications industry-Bell Telephone. Since the end of World War II, with equipment simplification and larger supplies of trained technicians, a definite trend toward shortening the length of the progression period has emerged. Union demands have certainly reflected these changed conditions, although during the last few years, ranges have sometimes been widened to meet the problems created by long-service technicians.

${ }^{72}$ There are some announcer-unionized stations, especially small radio-only operations which do not pay fees. Fees as a method of compensation are used by a substantial number of nonunion TV stations and some radio stations. There is sharp disagreement among station managers as to whether this is a desirable method of compensation.

${ }^{73}$ The fee is usually in lieu of overtime, provided it is at least equal to overtime compensation. 
formance of more specialized duties such as "emcee," disc jockey, news, farm editing, and sportscasting ${ }^{74}$ talent fees are now paid for an increasing number of routine job assignments-particularly in television. A typical fee schedule sets forth specific amounts of money to be paid for announcing under certain specific conditions. Fees vary with the length of time involved, radio or TV, sustaining or commercial or participating programs, spot announcements, on-camera or off-camera performances, special program work, local cut-ins on network shows, in-stretch or out-of-stretch, station-assigned or sponsor-selected, staff or free-lance, and other factors. The complexity of these schedules is such that they may easily occupy ten pages of a labor agreement. As might be expected, there is tremendous variation between stations (even competing ones) in both amount of fee and in the work for which fees are paid. $^{75}$

To add to the negotiating and payroll problems created by fees, some of the larger stations also enter into above-scale contracts of employment with individual performers-especially those stations which use the well-known personality as the basis of their programming. Where this is the practice, the union contract requires that the terms of the individual contract shall not be less favorable to the performer than those in the collective bargaining agreement. ${ }^{76}$

The same relationship between wages and market size noted above for technicians also prevails for announcers. However, where the typical technician maximum ranged from $\$ 75$ to $\$ 160$ in the smallest and largest markets, respectively, the comparable figures for announcers, including fees, would be $\$ 75$ to $\$ 200$ or $\$ 225$, with $\$ 1,000$ or more per week for top personalities at some large stations and at the networks. ${ }^{77}$

\section{Fringe Benefits}

Broadcasting has had the same postwar experience as most other industries-a steady liberalization of existing fringe benefits and the birth of others. Bargaining emphasis, however, has rarely concentrated on fringes. The basic reason for this may have been union success in augmenting total compensation directly by securing

An administrative ruling under the Fair Labor Standards Act has recognized this practice. Wage-Hour Administrator's Regulations, Pt. 550, as amended, Aug. 25, 1953, WHM 50:473.

${ }^{74}$ In some stations these functions are handled by staff special program announcers with a separate basic wage scale and separate fee schedule.

${ }^{75}$ In some stations, announcers are paid a percentage of the total business sold on their programs in lieu of or in addition to fees.

${ }^{70}$ In deciding that a station had not refused to bargain in good faith with AFTRA, the NLRB interpreted this to mean that the talent contract as a whole must be more favorable, but that individual items can be less favorable to the employee. Midland Broadcasting Co., 93 N.L.R.B. 455 (195I).

${ }^{77}$ At some of the larger stations, collective bargaining contract compensation (base salary plus fees) may occasionally result in earnings of as much as $\$ 250$ per week. The \$1,000 figure would be based on an individual above-scale contract.

The basis for the high compensation of top performers in broadcasting and elsewhere is an interesting subject. Before the turn of the century, an English economist, Alfred Marshall, offercd in his book, PRINCIPLEs of Economics (189o), the theory that wages for such occupations are high because the supply is rigidly limited. Recent experience involving the growth of television may indicate that the supply is not as limited as once thought. 
substantial boosts in wage rates. Perhaps secondary has been the relative disinterest of broadcast unions with health, welfare, and pension plans-among the most expensive fringe items. ${ }^{78}$ Only within the last year or so have there been a few indications that nonwage rate issues may occupy a larger place in future broadcast bargaining negotiations.

Briefly, what is the nature and level of fringe benefits in the radio and television broadcasting industry? Here is a summary.

(I) Overtime-usually at time and one-half, for work in excess of an eight-hour workday or forty-hour workweek, interrupting a ten- or twelve-hour rest period between shifts, when "called in" on days off or "called back" outside of the regular shift, and when insufficient notice (less than seventy-two hours-one week) is given of changes in weekly schedules. Double time is paid by a minority of stations for call-ins and call-backs, but is the dominant formula for worked holidays. ${ }^{79}$

(2) Vacation-minimum practice is one week after six months of service and two weeks after one year. "Going" practice in the larger markets, but less uniform, is a third week of vacation after varying periods of service averaging about five years; not infrequently, the third week or a fourth week of vacation is granted in lieu of premium pay for worked holidays.

(3) Health, Welfare, and Pension Plans-rarely found, although two weeks' sick leave is fairly common. The networks and a few stations in the largest markets have contracted with AFTRA for a pension-welfare plan wherein they contribute five per cent of the gross talent payroll. In effect in a few stations is the IBEW pension, requiring employers to contribute one per cent of the gross labor payroll for the IBEW bargaining units. This is an outgrowth of the union-financed plan begun in 1928. As in most industries, there are, of course, some unilateral plans not found in the labor agreement. These are found most often in stations owned by larger organizations, especially newspapers and insurance companies.

(4) Severance pay-found in a minority of contracts-probably more often in agreements covering announcers where the discharge clause may allow management to discharge performers who are "unsuitable" to the stations' programming needs. Severance pay is invariably based on length of service, with a prevailing pattern of one week per year up to a maximum of eight to twelve weeks.

(5) Night-shift differentials-exist in only some of the larger-market stations and, even here, are generally limited to the time period when the station is not on the air-I:00 or 2:00 A.M. $5: 00$ or 6:00 A.M.; ten per cent is perhaps the most usual premium.

70 U.S. Chamber of Commerce, Fringe Benefits, 1955, at 1o (1956).

${ }^{20}$ A guarantee of overtime pay of $3-6$ hours for call-ins and $2-4$ hours on call-backs is typical. 


\section{B. Job Protection}

Job protection is of major importance to a union member as an individual wage earner, and to a union as a continuing institution. As noted in the previous section, this has been one of the two key issues in broadcasting industry labor relations. The essence of job protection is control of the work. Its substance and scope is suggested by a union's concern for what work is covered, who does it, and how it is done. All unions have a general interest in these questions. The degree of interest varies widely. The variation depends on the structure of the industry, the job, and the nature of the unions which have organized the industry.

Broadcasting unions have shown a determined and, at times, almost paranoic interest in job protection. Why has this been so? First, the structure of the industry is such that bargaining units are relatively small, thus permitting employees to see readily the impact of changes or proposed changes in work assignments. Secondly, the operating jobs in the big stations and at the networks, where organization started, fall naturally into separate groups with distinct skill requirements. Finally, the unions first active and still dominant in the broadcasting field were craft or crafttype unions interested primarily in representing those with particular skills. The patterns these unions set are still largely with us today.

Craft unions are, by tradition, work-control conscious. However, this fact alone does not necessarily mean collective bargaining headaches. Where a skill is both substantial and distinct, and where its employment is not threatened by technology or changes in the nature of the product, all might be clear sailing once the initial bargaining relationship is set. Unfortunately, these conditions are seldom found. Certainly they have not existed in broadcasting. Even in the early days of broadcasting, small stations followed operational patterns not conducive to the craft type of organization. Advancing technology and changes in the nature of the product have created a situation in which management has striven to break down some of the separatism which once may have made more sense. This is the root of the job protection problem in broadcasting labor relations.

The heart of job protection is contract language, both its writing and its interpretation. Earlier it was suggested that job protection is concerned with what work is covered, who shall perform it, and how it shall be done. The "what" and the "who" are closely tied together in contract clauses. The typical IBEW contract, for example, contains a jurisdiction clause granting to technicians covered by the contract the operation and maintenance of all technical equipment used in sending a signal over the air waves. The term "technician" is not otherwise defined. Most contracts specifically add that no one else shall perform this work, and that a technician shall not be asked to perform other duties. NABET contracts normally include a comprehensive jurisdiction clause plus a listing of covered classifications, usually with a detailed description of the duties that shall be performed by each. AFTRA agreements are more often written in terms of contract unit coverage of 
those who "regularly or frequently" appear before the microphone or camera. ${ }^{80} \mathrm{~A}$ listing of at least staff duties is usually included. By this approach, work jurisdiction is thus written into the contract unit definition.

These are inclusive references. The work is defined, and the employees covered by the contract are designated to handle it, normally on an exclusive basis. Exceptions, if there are any, must be spelled out. For management, this has meant reluctant acceptance of the status quo, or an effort to retrieve a few scraps from a basic position already conceded. For the unions, it has meant hanging on to a simple, somewhat monolithic position: "The work is ours." Concessions there have been, some granted in informal agreements never appearing in the contracts and others reduced to writing only after substantial struggle involving many tears, much sweat, and, occasionally, some blood.

More specific references to some of the sore points will illustrate the nature of the problem. An announcer is assigned to pick up an interview at the airport with a portable tape recorder, which he can operate with almost no technical training. The chief engineer wants to handle some special maintenance work or stand an odd shift at the transmitter. On a local live show, the TV director may want to push the buttons involved in camera switching. Each of these involves the operation of technical equipment, although obviously in a relatively minor way. Each has given rise to a good many hours of argument in broadcasting labor relations.

A more drastic alteration in the method of operation takes place where a station wants to transfer the operation of the control board from technicians to announcers. This normally means the layoff of technicians, as was discussed in the previous section.

Where announcers are concerned, the conflict results from union desire to control the work for the benefit of its members and management's desire to get as much variety as possible on the air. The occasional use of other employees and outsiders for on-the-air performance is discouraged in part through the application of the union shop provision, with its requirement of union membership and the payment of substantial initiation fees. Union concern in this area springs in part from the practice of fee payments as a method of compensation. The loss of work may mean the loss of money. Of necessity, most contracts spell out exceptions for amateurs, public figures, and the like who appear on an infrequent basis. These exceptions are not as broad as most stations would like to have them.

Control over how the work shall be done has received a good deal of attention. It has centered around the number of people used on particular work. The Musicians Union, the most job-conscious of all unions in broadcasting, and perhaps the one with the most reason to be so, has, with what bargaining power it has left, tried to get commitments as to the number of musicians who shall be employed or, in the alternative, to get agreement that so much money per year will be spent for the services of musicians. Both formulas are found in industry agreements. The tech-

${ }^{80}$ Hampton Roads Broadcasting Co., Ioo N.L.R.B. 232 (I952). 
nical unions have pushed for job assignment quotas but with only limited success. A few large TV stations' contracts contain elaborate manning tables covering the technicians needed for particular types of programming. The development of simplified and semi-automatic equipment has emphasized the problem. With announcers, the principal problem relates to the present use of recorded voices and the eventual use of video tape. Insistence on having a "live" announcer on duty at all times has been one approach. Another is to put substantial fees and other limitations on recorded announcements played out of stretch. At many unionized stations, the substantial advantages of the flexible use of recorded program material have been prevented by union opposition and an unwillingness on the part of management to make it a "must" issue at the bargaining table.

Most contracts do not prevent management from introducing new equipment as long as such equipment is handled by the union involved, but this can be a problem where the equipment is such that two or more unions can lay some claim to its operation. Remote-control operation of certain types of transmitters has been approved within the past two years by the FCC. Where this method of operation is used, it can have substantial effect on the number of technicians employed. An already small bargaining unit may be cut in half or, in some cases, even abolished. Union concern in such a situation is readily understandable.

The over-all picture is a story of conflict-conflict between union efforts to control work and management efforts to operate as efficiently and as creatively as possible. Such a struggle is not unique in American industry. It has assumed greater proportions in broadcasting than in some industries for a number of reasons. Perhaps the most important is the fact that the industry was organized on a craft rather than on an industrial basis. ${ }^{81}$ As Professor Dunlop has pointed out, the pattern of organization makes a big difference on the subsequent bargaining relationship. ${ }^{82}$ Broadcasting was organized on a skill or semi-craft basis. Yet, in many respects, it is not ideally suited from an operational point of view to the craft concept. Studio production, whether at the network or the station, involves, for example, different skills, but most of them are used together in a single room and, for the most part, at the same time. Under such conditions, work-conscious unions become competitively concerned with work assignments-much more so than they would be if each occupied a separate department or a separate room. For management, this means overstaffing, inflexibility, and the ever-present possibility of a jurisdictional blow-up.

Changing methods of operation, due in part to improved technology and in part to changes in the product, have also been a factor. Most people resist change, even when it may be for the better. Change is a threat to security, and particularly so

\footnotetext{
${ }^{81}$ At a few stations, organization has been on a plant-wide basis. Sometimes a single contract has covered all those in the bargaining unit; in other situations, separate agreements covering the different basic skills have been written. Unfortunately, with several exceptions, craft concepts of work control have been carried over into these situations, thus nullifying gains that might otherwise have accrued.

${ }^{82}$ John T. Dunzop, Collective Bargaining; Principles and Cases 25-27 (1950).
} 
when it involves simplification of the production process because it then may mean dilution of skills or consolidation of work assignments.

The future course of events in this troublesome area is easy enough to picture: more conflict and more compromises. Competitive pressure on management for maximum efficiency is likely to increase. Intelligent management will undoubtedly insist on at least a gradual accommodation to the most logical and economical methods of operation. This is the history of American business in a competitive situation. Only overwhelming union bargaining power, which does not exist in most segments of broadcasting, can stem the tide. For the unions, the task is not easy. It is understandably difficult for a union to be statesmanlike where permanent layoffs are involved. Yet, it has to be recognized-and, indeed, is recognized by inteiligent trade unionists in broadcasting and elsewhere-that there is little security in jobs whose function is artificially maintained by a contract clause or work rule, and not by the necessities of the production process.

\section{$\mathrm{V}$}

\section{Legislation and Broadcasting Labor Relations}

There are three federal labor statutes that affect the relationship between broadcasters and their employees: the National Labor Relations Act, the Lea Act, and the Fair Labor Standards Act. Only the first two involve in any significant manner collective bargaining problems. Discussion will, therefore, be limited to these two. ${ }^{83}$

The original National Labor Relations Act (known as the Wagner Act) was passed in $1935 .{ }^{84}$ It had two important aspects: to prevent employer interference with the right of self-organization, and to set up the machinery for the selection of a bargaining agent. Broadcasters have seldom been involved in unfair labor practice cases before the Board. ${ }^{85}$ The election machinery, though not mandatory, has been increasingly used by broadcast management and broadcast unions since 1940 .

In 1947, the Taft-Hartley Act was passed, amending the Wagner Act. Contrary to popular impression, the original structure of the Wagner Act was left largely intact. One major wing was added: unfair labor practices for unions. Like most of American businessmen, broadcasters generally supported the revision, and, like most of organized labor, unions active in broadcasting opposed. The amendments have not

${ }^{83}$ The application of the Fair Labor Standards Act to radio and TV stations, particularly small-market stations, has given rise to many difficult problems. An accommodation of the operating necessities of small-market broadcasting to the simple, but rather inflexible, requirements of the law has not been easy. See statement of Charles $H$. Tower, National Association of Radio and Television Broadcasters, in Hearings Before the Subcommittee on Labor of the Senate Committee on Labor and Public Welfare on S. 1135, 85th Cong., Ist Sess. I88-219 (1957).

${ }^{86} 49$ STAT. 449-57 (1935), 29 U.S.C. \$\$ I5I-68 (x952).

${ }^{85}$ The most famous broadcasting unfair labor practice case went all the way to the Supreme Court, which refused to label as a violation of the law a station's discharge of technicians, who, outside of working hours, passed out leaflets criticizing the company program service. National Labor Relations Board v. Electrical Workers, 346 U.S. 464 (1953), reversing 202 F.2d $\times 86$ (D.C. Cir. 1952), and affirming 94 N.L.R.B. 1507 (195I). 
significantly altered broadcasting labor relations. ${ }^{86}$ Only four sections have had either actual or potential effect. They are the ones that deal with union security, secondary boycotts, jurisdictional disputes, and featherbedding.

Prior to Taft-Hartley, many broadcasting labor agreements contained closed-shop provisions, which not only required that employees be union members, but also that only union members be hired. The I947 amendments to the NLRA prohibited the closed shop, but permitted, in section 8(a) (3), the union shop, which requires union membership within thirty days after accepting employment. Most broadcasting agreements have been revised accordingly.

A secondary boycott is union economic pressure directed against one employer for the purpose of getting that employer to interrupt his business relationship (such as that of purchaser or supplier) with another employer with whom the union has a labor dispute. In passing section 8(b) (4)(A) of the Taft-Hartley Act, Congress intended to do away with all secondary boycotts ${ }^{87}$ and succeeded in prohibiting a good many of them..$^{88}$ Broadcasting before 1947 was not plagued with secondary boycotts, but the boycott potential was, and still is, tremendous. The network-station relationship, depending as it does on the instantaneous transmission of program material, is the perfect set-up for secondary boycott pressure. Without statutory

${ }^{86}$ So much emotional fervor surrounds discussion and even analysis of the Taft-Hartlcy Act that it is hard to evaluate its impact on labor relations in the United States. At the bargaining table, the relationship has been affected to some degree by at least three provisions of the law: the ban on the closed shop, the prohibition against secondary boycotts, and the restriction on voting by permanently replaced economic strikers. All three have adversely affected union bargaining strength, though not substantially in most cases. In the organizing of new bargaining units, the Act may have had a somewhat greater effect, and, again, from the union point of view, an adverse one. Just how much of an effect is difficult to say. Union claims that the Act hamstrings organizational effort by permitting cmployers "to get away with murder" in election campaigns is an oversimplification.

The Wagner Act restrictions on employer interference are contained in the Taft-Hartley Act. Interpretations, particularly in the area of employer discussion of unionization, may be somewhat less restrictive on management now than they were during the first seven or eight years of the Wagner Act, but the loosening up process had started well before r947. Union claims that well-advised cmploycrs can violate the spirit of the Act with impunity may have some degree of truth in a limited number of situations. This condition does not result from the Taft-Hartley Act as such. Morcover, it is a condition which is bound to exist to some degree with a statute which seeks to strike a balance in a conflicting and emotional social environment.

Organizational effort has, of course, been handicapped by the imposition of unfair labor practices for unions. If, however, the banned activity is coercive and its exercise would inhibit a free choice, there can be little quarrel with its prohibition. Perhaps more important than the provisions of the statute has been the opinion climate which gave rise to Taft-Hartley and which has attended it during its first ten years. This is a climate which is considerably more critical of certain types of union policy and actions than that which existed during the late ' 30 's and ' 40 's. It is a climate in which union organizers find it somewhat harder to persuade employees that the benefits from unionization' are worth the price.

Another basic factor which has contributed to union difficulty in bringing new members into the fold is the simple fact that for a whole host of nonlegal reasons, most of the unorganized arcas of American industry are harder to organize. Certainly this is the case in broadcasting.

${ }^{87}$ National Labor Relations Board v. Denver Building Trades Council, 341 U.S. 675 (I95I).

${ }^{88}$ One type of secondary boycott not prohibited is important in broadcasting: the sccondary sponsor boycott. This tactic, now quite common in industry-strike situations (as noted in an earlier section) involves union pressure on a sponsor to cease doing business with a struck station. The threat is that union members will not patronize the uncooperative advertiser. An organized refusal to buy the goods or services of a second employer is not prohibited by the present language of the boycott section of the Act. Crowley's Milk Co., Inc., ro2 N.L.R.B. 996 (1953), enforced 208 F.2d. 444 (3d Cir. 1953). 
protection, the networks, as neutral or third-party employers, could find themselves continually being dragged into affiliated-station labor problems. The law has almost completely removed this threat.

Jurisdictional disputes-disagreements usually between two unions as to which has control of a certain type of work-have been a major problem in network television. Such is often the case in a new industry or in an old one where new equipment or new work methods are being introduced, assuming, of course, that organization is on a craft or skill basis. Unions are competitively eager to stake out their claims. Section 8(b) (4)(D) of the Taft-Hartley Act prohibits strikes over jurisdictional disputes and section ro $(\mathrm{k})$ provides a procedure for the resolution of such disputes by the Board. ${ }^{89}$ The networks have been direct beneficiaries of these sections and so, of course, have affliated stations whose program services might otherwise have been interrupted. There are some station situations where the jurisdictional dispute sections of the Act might well be applied-for example, in disputes over the assignment of control-board work to announcers, or the operation of telemetering equipment by nontechnical personnel. No such cases have apparently been presented to the Board.

A close relative of the jurisdictional dispute is featherbedding-a union practice intended to be limited by section $8(\mathrm{~b})(6)$ of the Act. The term refers to union insistence on the employment or pay of more men than are needed to perform the

${ }^{80}$ The Board has generally taken the position that in a section ro(k) proceeding, it will merely determine whether section $8(\mathrm{~b})(4)(D)$ of the Act has been violated and will not rule as to which of the two unions or groups of employees should control a particular type of work, although the Board has, in some cases, made a type of work assignment determination by determining that the work is included in a pre-existing bargaining unit. See Feldesman, Work Assignment Disputes as Bargaining Unit 1ssues Under the National Labor Relations Act, as Amended, 6 Syracuse L. Rev. 239 (1955). The Third Circuit Court of Appeals criticized this view in NLRB v. Pipefitters Locals, 242 F.2d 722 (3rd Cir. 1957), but the Board apparently has not changed its mind. See, for example, Radio and Television Engineers Union, II9 N.L.R.B. No. 7I (1957), which involved a dispute between CBS technicians and stagehands over the handling of lights on remote telecasts. It should be said that there are many vexing practical as well as theoretical problems which will inevitably arise if the Board finally adopts the Third Circuit's view of the matter. Meanwhile, emplayers can rely for the prevention of jurisdictional disputes on the unfair labor practice section, $8(\mathrm{~b})(4)(D)$, and the damage suit section, $303(\mathrm{a})(4)$. The latter permits the bringing of a suit in the federal courts for damages caused by activity similar to that which constitutes a violation of section $8(b)(4)(D)$. See International Longshoremen's and Warehouses Union v. Juneau Corp., 342 U.S. 237 (1952), in which the Supreme Court affirmed an award of damages of $\$ 750,000$ aganist the defendant union.

Of the 65 decisions which the Board has issued involving determinations under section $10(\mathrm{k})$ of the Act, from its effective date in August 1947 through the end of June 1957, 6 have involved network broadcasting. The 6 cases are as follows: National Association of Broadcast Engineers and Technicians, 95 N.L.R.B. I470 (I95I), which involved an argument between NABET and IATSE over the operation of teleprompter equipment; National Association of Broadcast Engineers and Technicians, CIO, I03 N.L.R.B. 497 (1953), involving a dispute between NABET and IATSE over the operation of special effects projectors; Radio and Television Broadcast Engineers Local I212, IBEW, x03 N.L.R.B. 1256 (I953), a dispute between the IBEW and IATSE over the operation of front and rear screen projectors; National Association of Broadcast Engineers and Technicians, CIO, 105 N.L.R.B. No. 59 (I953), a dispute between NABET and IATSE over the handling and placing of lights on remote stage broadcasts; National Association of Broadcast Engineers and Technicians, CIO, I Io N.L.R.B. I233 (1954), a dispute between NABET and IATSE over the handling of lighting equipment on full pickup remotes; and Radio and Television Broadcast Engineers Local I2I2, IBEW, II 4 N.L.R.B. I354 (1955), a dispute between the IBEW and IATSE over certain types of film shooting work. 
work. Before 1947 , broadcasters had a good deal of experience with this problem -enough to get them and Congress sufficiently aroused to pass, in 1946, the Lea Act, which is an antifeatherbedding statute applying specifically to broadcasting. Fortunate it is, too, that broadcast management did not have to rely on Taft-Hartley protection. The language of section $8(b)(6)$, as construed in several key cases, seems to offer relatively little protection..$^{90}$

The Lea Act was passed in 1946 as an amendment to the Communications Act.1 It was inspired by the much publicized activities of the American Federation of Musicians in dealing with broadcasting companies and related organizations. ${ }^{22}$ Most of these activities were part of the union's blatant campaign to make more work for performing musicians. The purpose of the Act is to make unlawful efforts to compel a licensee under the Federal Communications Act: (I) to employ or pay for more employees than are needed; (2) to refrain from carrying educational and cultural programs performed by unpaid performers on a noncommercial basis; and (3) to interfere with, by exaction or otherwise, the production or use of records or transcriptions by licensees or any other person. Unlike the NLRA, the Lea Act is a criminal statute.

Shortly after the law was passed, a situation was apparently created by the union to test its constitutionality. The union demanded that a Chicago radio station double its employment of musicians from three to six, even though the employed three worked as music librarians rather than as performing musicians. The company refused; a strike was called; and a picket line was established. An indictment was brought, but the federal district court held the statute to be unconstitutional. ${ }^{23}$ On direct appeal by the Government, the Supreme Court reversed, with Justice Black writing the majority opinion. ${ }^{94}$ On remand, the federal district court found no violation of the law on the facts in a controversial decision which turned on the point that the defendant, Petrillo, was not shown to have knowledge that the licensee

${ }^{00}$ America Newspaper Publishers Ass'n v. NLRB, 345 U.S. xoo (1953); NLRB v. Gamble Enterprises, Inc., 345 U.S. II7 (I953). From these cases, the present rule seems to be that no violation of section 8(b) (6) will be found as long as the union wants its members to perform the work for which pay is being asked, no matter how little the employer may need to have it performed.

${ }^{21} 60$ STAT. 89 (1946), 47 U.S.C. $\$ 506$ (1952). The popular designation, the Lea Act, comes from the name of former Congressman Clarence F. Lea, of California, who played a leading part in the enactment of this legislation.

${ }^{92}$ See House Committee on Interstate and Foreign Commerce, Prohibiting Certain Coercive Practices Affecting Radio Broadcasting, H.R. Rep. No. 1508, pt. 1, 79th Cong., 2d Sess. 1-5 (1946); see also 92 Cong. Rec. $x_{543}$ (1946).

${ }^{93}$ United States v. Petrillo, 68 F. Supp. 845,850 (N.D. Ill. 1946). The District Court judge summarized the alleged constitutional deficiencies of the law as follows:

"The court finds it necessary to hold that the statute here involved in the application here sought to be made violates the Fifth Amendment because of indefiniteness and uncertainty in the definition of a criminal offense; violates the First Amendment by its restriction upon freedom of speech by peaceful picketing; violates the Fifth and Thirteenth Amendments by its restriction upon employment of labor; and violates the Fifth Amendment by an arbitrary classification as between employers and employees and as to other communication industries."

os United States v. Petrillo, 332. U.S. I (1946). The Supreme Court ruled only on the alleged invalidity of the statute in terms of the Fifth Amendment and passed the questions raised by the application of the first and thirteenth amendments as not being ripe for decision. 
had no need for the services of additional employees. ${ }^{95}$ The union thus won the battle, but lost the war.

The Petrillo case is the only action brought by the federal government under the Lea Act, but the statute has been construed in a series of New York decisions involving a dispute between WOR and the AFM over the employment of staff musicians. ${ }^{96}$ The parties were unable to agree on the retention of staff musicians. Following the termination of the contract requiring their employment, they were permanently laid off. The union set up picket lines and placed the company on an unfair list. Instead of requesting the United States Attorney to bring a Lea Act criminal prosecution, the company brought an action for an injunction in the New York courts. ${ }^{97}$ An appeal from the trial court's dismissal of the complaint was sustained on the grounds that the complaint, in alleging facts sufficient to constitute a violation of the Lea Act, set forth a cause of action. ${ }^{98}$

In a decision on the facts, the trial court enjoined the union from picketing and placing the station on an unfair list. ${ }^{99}$ The decision rested on two theories: first, that under existing New York case law, the object of the union action was unlawful and hence enjoinable; and, secondly, that the union's action constituted a breach of the Lea Act and thus gave rise to a civil remedy enforceable in the New York courts. The first theory is grounded in a leading New York case in which the musicians' union was enjoined from inducing other unions to enter into a combination to destroy a touring opera company because it used recorded rather than "live" music. $^{100}$ The second theory is based on the debatable principle that the violation

${ }^{05}$ United States v. Petrillo, 75 F. Supp. 176 (N.D. Ill. I948).

${ }^{\circ 0}$ The Lea Act has been given rather incidental consideration in two other civil cases, Gremio de Prensa, Radio, Teatro y Television de Puerto Rico v. Voice of Puerto Rico, Inc., 12I F. Supp. 63 (D. P.R. 1954); Lang-Worth Feature Programs, Inc. v. Manning, 27 NLRMM 25 II (N.Y. Sup. Ct. 195I). In the first case, the conduct complained of was found to be permitted by contract. The LangWorth case was an action by a transcription company against AFTRA alleging, among other things, a violation of the Lea Act in connection with AFTRA efforts to compel the company to sign the transcription code. The court, without detailed analysis, merely said that AFTRA's demand for reuse payments did not violate the law.

${ }^{07}$ General Teleradio, Inc. v. Manuti, 205 Misc. 655, I29 N.Y.S.2d 757 (Sup. Ct. 1954).

${ }^{88}$ General Teleradio, Inc. v. Manuti, 284 App. Div. 400, I3I N.Y.S.2d 365 (Ist Dep't I954).

${ }^{09}$ General Teleradio, Inc. v. Manuti, 133 N.Y.S.2d 362 (Sup. Ct. 1954).

${ }^{100}$ Opera on Tour, Inc. v. Weber, 285 N.Y. $348,355,357,34$ N.E. 2 d 349,35 I, 353 (I94I), cert. denied, 314 U.S. $6 \mathrm{IJ}_{5}$ ( $\mathrm{I} 94 \mathrm{I}$ ). Often cited from this decision is the following statement: "For a union to insist that machinery be discarded in order that manual labor may take its place and thus secure additional opportunity of employment is not a lawful labor objective." There may be some difficulty in reconciling this quotation with an earlier statement in the same opinion to the effect that: "Individually and collectively, the members of any union may at any time refuse to work because machinery is employed, or for any other reason, and may strike in doing so." It is hard to generalize as to the present status of state law on the legality of union efforts to prevent the use of labor-saving equipment. In a number of states, there are decisions proscribing such efforts in the more extreme situations. See Note, I36 A.L.R. 282 (1942). See also I Ludwio Teller, Law Governing Labor Disputes and Collective Bargaining 263-65 (1940). The problem in this area is the need for striking a delicate balance between a union's legitimate concern for employment opportunities for its members and layoffs which affect such employment opportunities, and management's basic concern with efficient low-cost operation. And beyond these partisan interests, of course, is the concern of the society as a whole for the employment of its members and the efficient production of goods and services.

State court action premised on the Lea Act may be subject to the pre-emption doctrine enunciated by 
of a federal criminal statute, which itself contains no civil remedies, gives rise to a right of civil relief in state courts. ${ }^{101}$

The effect of the Lea Act on broadcasting labor relations has been a good deal more significant than the cases might indicate. The employment of unwanted staff musicians has ceased to be a problem in station bargaining. The act is not, of course, limited in its application to the employment of standby musicans. Its prohibitions are drawn in the broadest terms-broad enough, in all probability, to cover other instances of featherbedding in broadcasting. The announcer-control issue comes readily to mind. Restrictions on the use of recorded voices or of unpaid public personalities on noncommercial programs may be others. Once agreed to, of course, such commitments are binding until the contract is terminated. Nevertheless, at the bargaining table, the force of the Act may well be behind station management on many of these issues. Broadcasters have been reluctant to use this power because they feel, and rightly, that criminal prosecution is a drastic remedy to be used only as a last resort. Furthermore, they feel that, given any degree of reason, the complex human problems involved in accommodation to: changing conditions are, under most circumstances, best worked out in the framework of collective bargaining.

\section{VI}

\section{Conclusion}

At the outset of this article, it was stated that the labor relations of an industry are determined by the nature of the product, the structure of the industry, and the jobs themselves. A review of the important characteristics of broadcasting labor relations shows the importance of these underlying factors.

First, unionization is limited, both in terms of percentage of employees organized and, even more so, in terms of percentage of establishments organized. The governing factor here is an industry structure characterized by a large number of geographically dispersed producing units, most of which employ relatively few people. Growth of the industry, as measured by an increase in the number of producing units, is, over the next five years, likely to occur primarily in the small-station category. No significant increase in employment by existing units is expected; indeed, in some segments of the industry, a reduction seems more likely. Unionization, therefore, is not apt to significantly increase in terms of the number of employees covered or in the number of units covered.

Secondly, collective bargaining, particularly in the major centers, has resulted in contract terms which are unusually favorable to the employees covered. Profitability of the companies involved in the pace-setting negotiations-a profitability deriving

the Supreme Court in Garner v. Teamsters, 336 U.S. 485 (I953)-a point discussed in the first Generat Teleradio decision, but not in the others. On the other hand, state court action premised on unlawful or tortious interference with the business of another may be sustainable, at least in so far as an action for damages is concerned. Construction Workers v. Laburnum Corp., 347 U.S. 656 (1954).

${ }^{101}$ See Note, 55 Colum. L. REv. 754 (1955). 
from a number of structural characteristics such as the growth of the industry and limitation on entry-has been an important contributing factor. Equally important: has been the impact of the nature of the broadcast service and the methods of producing it on management's attitude towards work stoppages-that is, an inability or an unwillingness to take a strike. Both factors seem to be undergoing a change. Consequently, greater resistance to union demands, and, thus, smaller advances seem probable over the next five years.

Finally, the major source of collective bargaining conflict has been job protection -a direct outgrowth of the nature of the jobs, especially in network and largemarket broadcasting. In part, at least, because of the relationship between these jobs and jobs in other industries, organization of the industry took place on a craft or skill rather than on an industrial basis. The conflict has manifested itself in a dedicated union concern for control of work and a stubborn resistance to changes in methods of operations. Broadcast management's unique involvement in federal labor legislation, the Lea Act, grows from this soil. The resolution of this basic conflict has been a slow and sometimes painful process of compromise and adjust-ment. The end is not yet in sight.

These three characteristics all suggest problems for the future. Their solution will call for understanding and patience-understanding of the legitimate interests: on the opposite side of the bargaining table, and patience to work them out in the: give-and-take of negotiations rather than through resort to force. 